\title{
The prosodic representation of clitics in Irish*
}

\author{
Antony Dubach Green \\ Zentrum für Allgemeine Sprachwissenschaft
}

\section{Introduction}

The status of clitic groups in the prosodic hierarchy has been a topic of debate among phonologists in recent years. While some authors (e.g. Nespor \& Vogel 1986, Hayes 1989) have considered the clitic group to be a separate level of the prosodic hierarchy, located between the prosodic word (henceforth pword) and the phonological phrase, other authors have argued that clitic groups do not comprise an independent constituent and that host + clitic sequences are simply one variety of pword (e.g. Selkirk 1986, Booij 1996), or that clitic groups are pwords in some languages and phonological or intonational phrases in other languages (e.g. Inkelas 1989, Zec \& Inkelas 1991). Selkirk (1995) has argued that it is not necessary to assume an independent prosodic category clitic group. As she points out, a sequence of function word plus lexical word can be parsed in four different ways using only the categories phonological phrase $(\phi)$ and pword $(\omega)$. She makes the strong claim that the cross-linguistic variety of behaviour seen in function word-lexical word sequences can be accounted for by means of one of the following parses: First, the function word and lexical word may be separate pwords: $\phi\left(\omega(\mathrm{fnc}) \omega_{\omega}(\mathrm{lex})\right)(\phi=$ phonological phrase; $\omega=$ pword). In this case, the function word is not a clitic. In the remaining three parses, the function word is a clitic, that is, it does not comprise a pword by itself. Following Selkirk's definitions, a free clitic is incorporated directly into the phonological phrase, as a sister of the pword containing the lexical word: $\phi($ fnc $\omega($ lex $))$. An internal clitic is incorporated into the same pword as the lexical word: $\phi(\omega($ fnc lex $))$. An affixal clitic is similar to an internal clitic, but the lexical word comprises its own pword (assuming pwords can be recursive $): \phi\left(\omega\left(\right.\right.$ fnc $\omega_{\omega}($ lex $\left.\left.)\right)\right)$. Selkirk shows that each type of clitic structure is attested; there are three dialects of Neo-Štokavian that differ from one another in that one has free clitics, another has internal clitics and the third has affixal clitics. Similarly, Peperkamp (1997) shows that three closely related Italian languages differ according to which type of clitic structure is employed. While most authors have implicitly assumed that any given language or dialect has just one type of clitic structure, free, internal or affixal, Hall (1999) argues that certain enclitics in German are pword-internal while others are pwordexternal, thus showing that more than one type of clitic structure may be found within the same language or dialect.

In this paper I will come to a similar conclusion for Irish, namely that proclitics in this language are usually free, i.e. $\phi\left(\right.$ fnc $\left.\omega_{\omega}(\mathrm{lex})\right)$, but that under certain circumstances the final consonant of a proclitic may become the onset of a vowel-initial lexical word. ${ }^{1}$ In the event that the clitic consists solely of a consonant, an internal clitic structure will arise: $\phi(\omega($ fnc lex $)){ }^{2}$ I will follow Optimality Theory (Prince \& Smolensky 1993) and argue that constraints are ranked in such a way as to allow the free clitic structure in most instances, but that considerations of syllabification can compel the internal structure instead. In $\S$ 2 I present evidence from various independent areas of Irish phonology that points to a free-clitic analysis of Irish. In $\S 3$ I examine the behaviour of proclitics before vowel-initial stems. If a clitic ends in a placeless vowel, the vowel is elided before a vowel-initial stem, and the consonant will be incorporated as the onset of the first syllable of the host pword, resulting in an internal-clitic structure. And in consonant-final proclitics, resyllabification will result in the splitting of a morpheme (namely the clitic) across a phonological boundary (namely the left edge of the pword), which provides further evidence for the independence of phonological structure from morphosyntactic structure (cf. Inkelas 1989, Peperkamp 1997). I will argue that resyllabification between a consonant-final proclitic and a vowel-initial lexical word is depend- 
ent on syntactic structure; namely, there is resyllabification only when the two are not separated by a trace. In $\S 4$ I discuss the motivations behind the assumptions I make regarding the structure of copular sentences; finally, $\S 5$ concludes the paper.

\section{Evidence for free clitics in Irish}

Of the four types of possible parsings for ${ }_{\phi}($ fnc lex), only in the free clitic case does the left edge of the function word not correspond to the left edge of a pword: in $\phi_{\phi}\left(\mathrm{fnc}_{\omega}(\mathrm{lex})\right)$ the function word is external to the pword. In the other cases, where the function word is a pword, i.e. $\phi\left(\omega(\mathrm{fnc}) \omega_{\omega}(\mathrm{lex})\right)$, where it is an internal clitic, i.e. $\phi(\omega($ fnc lex $))$, and where it is an affixal clitic, i.e. $\phi(\omega($ fnc $\omega($ lex $)))$, the function word is at the left edge of a pword. If evidence from a language can be found that a function word that otherwise displays proclitic behaviour (phonetic reduction or absence of stress, dependence on a following host) is not at $\omega$ (, then we know that we are dealing with a free clitic. In Irish, evidence that certain proclitic function words are not at $\omega_{\omega}$, and are therefore free clitics, comes from facts of place agreement, the absence of epenthesis in certain consonant clusters with falling sonority and the behaviour of phrase-initial $s+$ consonant clusters. In this section, I will review the evidence in favour of the free-clitic analysis one step at a time, beginning with the evidence from place agreement.

\subsection{Evidence from place agreement}

All consonants in Irish except [h] can be either velarised or palatalised. Velarised labials are realised as labiovelarised (i.e. velarised and rounded) before front vowels. The velarised/palatalised contrast is phonemic in Irish (cf. buion $\left[\mathrm{b}^{\mathrm{w}} \mathrm{i}: \mathrm{n}^{\gamma}\right]$ 'class' (FP) vs. bionn $\left[\mathrm{b}^{\mathrm{j}} \mathrm{i}: \mathrm{n}^{\gamma}\right]$ 'be' (present habitual) (de Bhaldraithe 1953, 107); cad $\left[\mathrm{k}^{\gamma} \mathrm{ad}^{\gamma}\right]$ 'what?' vs. cead [ $\left.\mathrm{k}^{\mathrm{j}} \mathrm{ad}^{\gamma}\right]$ 'permission' (both FP)). Velarisation is not always acoustically prominent, and is not usually indicated in transcription; thus [bi:n, kad], etc., stand for $\left[\mathrm{b}^{\mathrm{w}} \mathrm{i}: \mathrm{n}^{\gamma}\right.$, $\left.\mathrm{k}^{\gamma} \mathrm{ad}^{\gamma}\right]$, etc.; however, I will use the $\left[^{\gamma}\right]$ sign below when I wish to emphasise that a particular consonant is velarised and not palatalised. The consonant phonemes of Irish are listed in (1).

(1) The consonant phonemes of Irish

\begin{tabular}{r||ccc|ccc|c|c}
\multicolumn{1}{l||}{} & \multicolumn{2}{c|}{ Velarised } & \multicolumn{2}{|c|}{ Palatalised } & No contrast \\
\hline \hline Voiceless stops & $\mathrm{p}$ & $\mathrm{t}$ & $\mathrm{k}$ & $\mathrm{p}^{\mathrm{j}}$ & $\mathrm{t}^{\mathrm{j}}$ & $\mathrm{k}^{\mathrm{j}}$ & \\
\hline Voiced stops & $\mathrm{b}$ & $\mathrm{d}$ & $\mathrm{g}$ & $\mathrm{b}^{\mathrm{j}}$ & $\mathrm{d}^{\mathrm{j}}$ & $\mathrm{g}^{\mathrm{j}}$ & \\
\hline Vcls fricatives & $\mathrm{f}$ & $\mathrm{s}$ & $\mathrm{x}$ & $\mathrm{f}^{\mathrm{j}}$ & $\int$ & $\mathrm{c}$ & $\mathrm{h}$ \\
\hline Vcd fricatives & $\mathrm{v}$ & & $\gamma$ & $\mathrm{v}^{\mathrm{j}}$ & & $\mathrm{j}$ & \\
\hline Nasals & $\mathrm{m}$ & $\mathrm{n}$ & $\eta$ & $\mathrm{m}^{\mathrm{j}}$ & $\mathrm{n}^{\mathrm{j}}$ & $\eta^{\mathrm{j}}$ & \\
\hline Liquids & $\mathrm{l}$ & $\mathrm{r}$ & & $\mathrm{r}^{\mathrm{j}}$ & $\mathrm{r}^{\mathrm{j}}$ & &
\end{tabular}

Ní Chiosáin $(1991,1994)$ shows that the contrast in Irish is a function of the feature [back]: velarised consonants are marked [+back] and palatalised consonants as [-back]. The exact phonetic realisation of [ \pm back] on consonants varies across dialects and across places of articulation, but for simplicity of transcription I indicate most [-back] (i.e. palatalised) consonants with a following $\left.{ }^{j}\right]$. The exceptions to this convention are that $/ \int, c ̧, j /\left(\right.$ rather than $/ s^{j}, x^{j}, \gamma^{j} /$ ) are the [-back] equivalents of $/ s, x, \gamma /$ respectively. (The pronunciation of $/ \mathrm{j} /$ varies between a palatal glide $/ \mathrm{j} /$ before vowels and a voiced palatal fricative $/ \mathfrak{j} /$ before consonants.)

Within lexical words in Irish, adjacent consonants must agree in secondary place, that is, they must both be palatalised or both be velarised. ${ }^{3}$ Examples of well-formed words and ill-formed possible alternatives are illustrated in (2). 
(2) Secondary place agreement (FP unless otherwise marked)
a. $\quad b^{j} 1^{j}{ }_{i \ni n}^{j}$ bliain 'year' $* b^{\gamma} 1^{j}{ }_{i \ni n}{ }^{j}$
b. $\mathrm{kil}^{\mathrm{j}} \mathrm{t}^{\mathrm{j}}$ cuilt 'quilt' ${ }^{\mathrm{k}} \mathrm{kil}^{\mathrm{j}} \mathrm{t}^{\mathrm{y}}$
c. fol ${ }^{\gamma} \mathrm{k}^{\gamma} \ni$ folcadh 'bath' $* \mathrm{fol}^{\gamma} \mathrm{k}^{\mathrm{j}_{\ni}}$
d. $\quad \mathrm{d}^{\mathrm{j}} \mathrm{e}: \mathrm{Jt}_{\mathrm{t}}^{\mathrm{j}} \mathrm{f}^{\mathrm{i}} \mathrm{i}$ : d'éistfi 'one would listen' $* \mathrm{~d}^{\mathrm{j}} \mathrm{e}: \mathrm{dt}^{\mathrm{j}} \mathrm{f}^{\mathrm{w}} \mathrm{i}$ :
(Ó Baoill 1986, 50)
e. $\quad a m^{\mathrm{j}} \int_{\ni r^{\mathrm{j}}}$ aimsir 'weather' $* \mathrm{am}^{\mathrm{j}} \mathrm{s \ni r}^{\mathrm{j}}$
f. $\gamma n^{\gamma} \mathrm{a}$ h ghnáth 'habit' (len.) *jn ${ }^{\gamma} \mathrm{a}: \mathrm{h}$ (Munster: Ó Cuív 1944, 43)
g. $\quad \mathrm{ka} \int \mathrm{m}^{\gamma}{ }^{\gamma} \mathrm{rr}^{\mathrm{j}}$ caismirt 'conflict' * $\mathrm{kasm}^{\mathrm{j}} \mathrm{j} \mathrm{rt}^{\mathrm{j}}$
h. $\mathrm{t}^{\gamma} \mathrm{n}^{\gamma} \mathrm{u}$ : tnuth 'longing' $* \mathrm{t}^{\gamma} \mathrm{n}^{\mathrm{j}} \mathrm{u}$ :
i. $\mathrm{k}^{\mathrm{j}} \mathrm{j}^{\mathrm{j}}$ as cleas 'trick' ${ }^{\mathrm{j}} \mathrm{k}^{\mathrm{j}} \mathrm{l}^{\gamma}$ as
j. $\operatorname{kor}^{\gamma} \mathrm{p}^{\gamma} \quad \operatorname{corp} \quad$ 'body' ${ }^{\mathrm{k}} \operatorname{kor}^{\mathrm{j}} \mathrm{p}^{\gamma}$

Across a word boundary, however, two consonants need not agree in secondary place, e.g. in d'ól sé [d $\left.\supset:{ }^{\gamma} \int_{\ni}\right]$ 'he drank' (Ulster: Hughes 1986, 242). Nevertheless, right-to-left [back] assimilation occasionally occurs across word boundaries, as shown by the variant $\left[\mathrm{d} \supset: 1^{1} \int \ni\right]$. But [back] assimilation is optional at a word boundary, whereas within a word it is obligatory. In other words, while $\left[\mathrm{d} \supset: 1^{\gamma} \int_{\ni}\right]$ is a possible (perhaps even the more common) pronunciation of d'ól sé, a word like milseog 'dessert' (FP) can be only

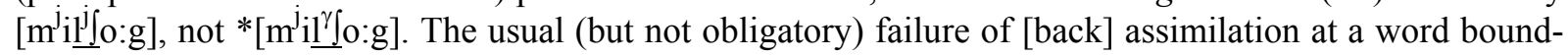
ary holds both after lexical words and after clitics, as shown in (3) and (4). The border between a proclitic and its host is indicated by \#.

(3) No secondary place assimilation after a lexical word

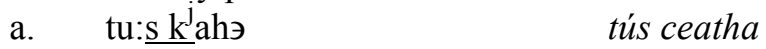
'the beginning of a shower' (Quiggin 1906, 194)
b. $\quad \mathrm{k}^{\mathrm{j}} \mathrm{ah}_{\mathrm{r}} \mathrm{r}_{\mathrm{g}}^{\mathrm{j} \mathrm{r}_{\mathrm{j}} \mathrm{e}} \mathrm{si} \quad \quad$ ceathrar gréasai
'four shoemakers' (Connacht: de Búrca 1958, 84)

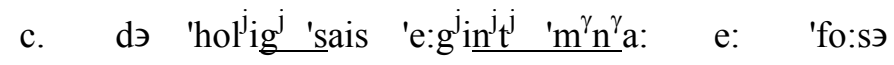
Do thoiligh saghas éigint mná é a phósadh.
PAST consent sort some woman.GEN himto marry
'Some sort of woman consented to marry him.'
(Munster: Ó Cuív 1944, 87)

(4) No secondary place assimilation after a clitic
a. $\quad \mathrm{fr}^{\mathrm{j}} \mathrm{i}: \mathrm{d}^{\mathrm{j}}$ \#xaihərahэ
fríd chathaoireacha
(Ulster: Hughes 1986, 52)
b. $\quad$ ax\#t $^{j} i^{j}{ }^{j} n^{j} j \mathrm{i}$ :
'but she comes'
ach tigeann si
(Connacht: Mhac an Fhailigh 1968, 112)

There is an additional type of place assimilation within lexical words in Irish: coda nasals must agree with following stops not only in secondary place (i.e. for [back]), but also in primary place of articulation, 
i.e. labial, coronal or dorsal. Examples are shown in (5).

(5) Nasal place agreement (all FP)

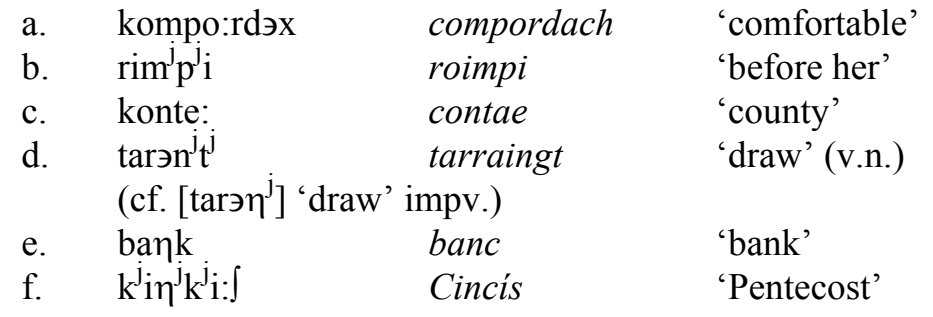

Like [back] assimilation, nasal assimilation is only sporadically attested across a word boundary. If there is nasal assimilation across a word boundary, it can be triggered by a following fricative as well as a stop, which is not the case word-internally. An example between two lexical words is [an ${ }^{j}{ }^{j}: \eta^{j} k^{j}$ iərho:g] aithnionn ciaróg 'a beetle recognises' ${ }^{4}$ (Connacht: de Búrca 1958, 68); examples in clitic + host constructions include [эm\#ba:d] an bád 'the boat' (Ulster: Hamilton 1974, 145) and [o:ฤ\#xrox] ón chroch 'from the gallows' (Munster: Breatnach 1947, 100). But in general, nasal assimilation does not occur across word boundaries, as the examples in (6) and (7) show.

(6) No nasal assimilation after a lexical/prosodic word
a. $\quad b^{\mathrm{j}}$ oga:n $\mathrm{f}^{\mathrm{i}} \mathrm{i} \mathrm{x} \quad$ beagán fiacha
'a small amount of debts'
(Connacht: de Bhaldraithe 1945, 78)
b. $\quad \mathrm{er}^{\mathrm{j}} \mathrm{v}^{\mathrm{j}} \mathrm{il}^{\mathrm{j}}{ }^{\mathrm{j}}$ pontэ $\quad$ ar mhilliún punta
'for a million pounds'
(Ulster: Hamilton 1974, 26)
c. $\quad$ sla:n $n^{\mathrm{j}} \mathfrak{t}^{\mathrm{j}} \ni$ gan slaida: $\underline{\mathrm{xu}} \mathrm{t}$
sláinte gan slaghdán chugat
'health without a cold to you'
(Munster: Breatnach 1947, 93)
d. $\quad \mathrm{jin}^{\mathrm{j}} \mathrm{b}^{\mathrm{j}}$ an $\ni \mathrm{t}^{\mathrm{j}} \mathrm{i}$ : dhein bean an $t^{\prime}$
'the landlady made'
(Munster: Breatnach 1947, 97)

(7) No nasal assimilation between clitic and host
a. gan\# $\mathrm{v}^{\mathrm{j}} \mathrm{r}^{\mathrm{j}} \mathrm{i}$ : gan bhri' 'without strength'
(Ulster: Sommerfelt 1965, 378)
b. gэn\#xõ:li: don chomhla 'to the door'
(Connacht: Mhac an Fhailigh 1968, 114)
c. эn\#garsu:n an garsún 'the boy'
(Munster: Breatnach 1947, 94)
d. e:n\#f into aon phionta 'any pint'
(Connacht: de Bhaldraithe 1953, 151)
e. э#ㅁ $\mathrm{p}^{\mathrm{j}} \mathrm{i}: \mathrm{s}$ an piosa 'the piece'

(Munster: Breatnach 1947, 100) 
Since [back] assimilation and nasal assimilation are obligatory within a lexical word, but optional across a word boundary, it is reasonable to assume that the domain of these processes is the pword: within a pword, place agreement is obligatory, while across the $\omega_{\omega}$ (boundary, spreading is optional. The absence of place agreement in clitic + host cases like (4) and (7) provides additional evidence for the free-clitic analysis: functional proclitics are external to the pword of the following host. In the remainder of this paper I will assume that these pword-external clitics are associated to the phonological phrase, rather than some higher element (intonational phrase, utterance), but nothing crucial hangs on this decision. This analysis is also supported by the absence of epenthesis into certain consonant clusters, as shown in the next subsection.

\subsection{Evidence from falling sonority clusters}

In Irish, an epenthetic vowel is inserted into a consonant cluster with relatively shallow falling sonority when preceded by a short vowel (Ó Siadhail 1989, 20 ff.; Ní Chiosáin 1991, 178 ff.; 1995b; 1999). In practice, these clusters include those of coronal sonorant $(l, r, n)$ followed by $m$, a fricative or voiced stop. This process occurs within lexical words, as the examples in (8) show.

(8) Epenthesis into falling-sonority cluster (FP unless otherwise noted)
a. $\quad \operatorname{an}^{\mathrm{j}} \mathrm{v}^{\mathrm{j}} \mathrm{i}$ :
b. $\quad$ arэma $: i^{j}$
ainmhi
'animal'
c. $\quad \underline{a b b} x^{j}$
armáil
'armament'
(Hamilton 1974, 234)
d. djarəga:n
Albain
'Scotland'
e. $\operatorname{\int an\ni xi:}$
f. $\int \underline{\mathrm{e}^{j}{ }^{j} \mathrm{j}} \mathrm{i}: \int$
deargán
'sea-bream'
'storyteller'
seirbhis
'service'

This epenthesis is not found, however, at word boundaries, including the boundary between clitic and host, as shown in the examples in (9) and (10).

(9) No epenthesis after a lexical word
a. b ${ }^{j}$ an voxt bean bhocht 'a poor woman'
(Connacht: de Búrca 1958, 96)
b. farmanihi: fear meanaithi 'a man of awls' (Munster: Ó Cuív 1944, 85)
c. $\quad \mathrm{b}^{\mathrm{w}} \mathrm{i}: \mathrm{x} \underline{1}^{\mathrm{j}} \mathrm{b}^{\mathrm{j}} \mathrm{ig} \quad$ buachaill beag 'a little boy'
(Ulster: Quiggin 1906, 208)

(10) No epenthesis between clitic and host
a. $\quad \mathrm{er}^{\mathrm{j}}$ \#gu:1
(Quiggin 1906, 52)
b. $\quad \mathrm{d}^{\mathrm{j}}$ n $^{\mathrm{j}} \mathrm{x}_{\mathrm{x}} \mathrm{u}: \mathrm{g}^{\mathrm{j}}{ }_{\ni \mathrm{r}} \quad$ den chúigear 'of the five people' (Munster: Breatnach 1947, 98)

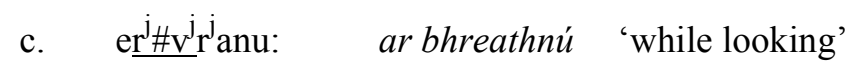
(Connacht: de Bhaldraithe 1945, 78)

The failure of epenthesis here is further evidence in favour of the free-clitic analysis of Irish, since epenthesis would be expected in every case in (10) if the proclitic and its host were in the same pword. 
More evidence in favour of the free-clitic analysis comes from the behaviour of clusters of $s+$ consonant, as we see in the next subsection.

\subsection{Evidence from $\mathbf{s}$-clusters}

In word-initial position, Irish allows $s$ to be followed by any voiceless stop, which in turn may be followed by a liquid. An exception is that no Irish word begins with $s t l-.^{5}$ Initial $s$ may also be followed by a liquid or nasal. In general, the consonants within a cluster agree in the feature [back]: all consonants in the cluster are either velarised ([+back]) or palatalised ([-back]). An exception is that $s$ is never palatalised before labials word-initially, nor is $s r$ ever palatalised. Examples of word-initial $s$-clusters are shown in (11).

(11) Word-initial $s$-clusters in Irish (all FP)

\begin{tabular}{|c|c|c|}
\hline spo:rt & spórt & 'sport' \\
\hline $\operatorname{sp}^{\mathrm{j}} \mathrm{r}^{\mathrm{j}} \mathrm{e}: \mathrm{x}$ & spréach & ‘spark’ \\
\hline stad & stad & 'stop' \\
\hline $\int \mathrm{t}^{\mathrm{j}} \mathrm{al}$ & steall & 'splash' \\
\hline $\int \mathrm{t}^{\mathrm{j}} \mathrm{j}^{\mathrm{j}}$ & striapach & 'harlot' \\
\hline skada:n & scadán & 'herring' \\
\hline $\int \mathrm{k}^{\mathrm{j}} \mathrm{e}: 1$ & scéal & 'story’ \\
\hline skla:v ${ }^{\mathrm{w}}$ iэxt & sclábhaiocht & 'slavery' \\
\hline sla:n & slán & 'safe' \\
\hline $\int \mathrm{l}_{\mathrm{i}}^{\mathrm{i}}$ & slí & 'way, path' \\
\hline sra: $\mathrm{d}^{\mathrm{j}}$ & sráid & 'street' \\
\hline $\operatorname{sna}^{j} \mathrm{v}$ & snámh & ‘swim’ \\
\hline $\int n^{\mathrm{j}} \mathrm{axt}$ & sneachta & ‘snow’ \\
\hline n. $\quad$ sm $^{\mathrm{j}_{\text {ir }}}$ & smior & 'marrow' \\
\hline
\end{tabular}

Irish is similar to English in that word-initial voiceless stops are aspirated, but voiceless stops after $s$ are unaspirated. Thus we can contrast the unaspirated stop of [ $\left[\mathrm{k}^{\mathrm{j}} \mathrm{e}: 1\right]$ scéal 'story' with the aspirated stop of $\left[\mathrm{k}^{\mathrm{jh}} \mathrm{e}: \mathrm{l}^{\mathrm{j}} \ni\right]$ céile 'companion'. Now the copular particle in Irish is the proclitic is, which has the full pronunciation [is] and an aphaeretic pronunciation $\left[s \sim \int\right] .{ }^{6}$ When the aphaeretic form precedes a host word

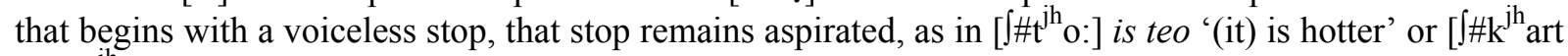
$\sim \mathrm{s}^{\mathrm{j}} \mathrm{K}^{\mathrm{jh}}$ art] is ceart '(it) is right' (Breatnach 1947, 76). Additionally, as the last example shows, the $s$ of the copula need not agree with the following consonant in the feature [back]: the $s$ of [s\# $\mathrm{k}^{\mathrm{jh}}$ art] is velarised while the $k$ is palatalised. (Assimilation is possible as well, as shown by the variant [ $\left[\# \mathrm{k}^{\mathrm{jh}}\right.$ art].) This contrasts with true word-initial cases like scéal, which can only be $\left[\int \mathrm{k}^{\mathrm{j}} \mathrm{e}: 1\right]$ and $\operatorname{not}^{*}\left[\mathrm{sk}^{\mathrm{j}} \mathrm{e}: 1\right]$, ${ }^{*}\left[\mathrm{k}^{\mathrm{jh}} \mathrm{e}: 1\right]$ or $*\left[\mathrm{sk}^{\mathrm{jh}} \mathrm{e}: 1\right]$. So $s+$ voiceless stop clusters across the clitic + host boundary differ from those in true wordinitial position in two ways: in aspiration of the voiceless stop and in secondary place assimilation.

Furthermore, the aphaeretic form of the clitic is can precede $f$-initial words in phrases like is fearr

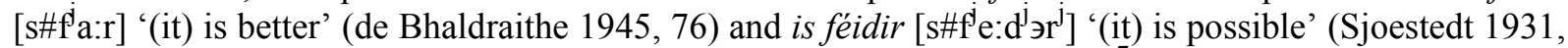
158 ), thus introducing a cluster $s f$ that is unattested in word-initial position. ${ }^{7}$ Since the $s+$ consonant clusters found at the juncture of clitic + host are quite different from those permitted at word-initial position, it is reasonable to deduce that a clitic in Irish is not, in general, part of its host's pword, but is rather a free clitic, external to the pword-even when the clitic itself is non-syllabic, as these cases with the reduced form of the copula show. The prosodic structures of the aphaeretic copula + host examples seen in this section are thus as listed in (12). 
(12) Aphaeretic copula + host sequences
a. $\quad \phi\left(\left(\#_{\omega}\left(\mathrm{t}^{\mathrm{jh}} \mathrm{O}:\right)\right)\right.$
is teo '(it) is hotter'
b. $\quad \phi\left(\int \#_{\omega}\left(\mathrm{k}^{\mathrm{jh}}\right.\right.$ art $\left.)\right) \sim \phi\left(\mathrm{s} \#_{\omega}\left(\mathrm{k}^{\mathrm{jh}}\right.\right.$ art $\left.)\right)$
is ceart
'(it) is right'
c. $\phi\left(\mathrm{s} \#_{\omega}(\mathrm{fa}: \mathrm{r})\right)$
is fearr
'(it) is better'

I leave aside for the moment a theoretical explanation of why the copula is not incorporated into the pword of the host, and merely make the descriptive observation that it appears to be pword-external. I return to a theoretical analysis below in $\S 3.3$.

We have now seen a variety of data from Irish indicating that clitics in this language are free, that is, they are external to the pword. The evidence we have examined comes from facts of place assimilation, epenthesis into consonant clusters and the behaviour of $s$-clusters. At this point, we can turn to an Optimality-Theoretical analysis and examine the constraint interaction that results in the observed structure.

As Selkirk (1995) shows, the parsing $\phi\left(f n c{ }_{\omega}(\mathrm{lex})\right)$ (where fnc $=$ clitic function word and lex $=$ host lexical word), which seems to be the usual case in Irish, results from the ranking of PRWDCONSTRAINTLEFT (13) above $\operatorname{EXH}_{\phi}$ (14).

(13) PRWdCONL (Selkirk 1995)

Align-L( $\omega$, Lex $)$

The left edge of every pword is aligned with the left edge of a lexical word.

(14) $\mathrm{EXH}_{\phi}($ Selkirk 1995)

No phonological phrase immediately dominates a foot, syllable, mora or segment.

As the tableau in (15) shows, using the phrase [ $\mathrm{er}^{\mathrm{j}} \# \mathrm{v}^{\mathrm{j}} \mathrm{r}^{\mathrm{j}}$ anu:] ar bhreathnú 'while looking' (10c) as an example, it is preferable to keep the left edge of the pword aligned with the left edge of the lexical word and to keep the function word outside of any pword, at the cost of allowing the phonological phrase to immediately dominate a syllable. The winning candidate (15a) has the free-clitic structure; an internal clitic (15b) or affixal clitic (15c) would fail by having a pword that is not left-aligned with a lexical word. In the failing candidates I take for granted that the epenthesis and stress placement expected within a pword would be present in these forms if they had surfaced; I will not show the constraint interaction resulting in epenthesis and pword-initial stress.

\begin{tabular}{|c|c|c|c|}
\hline (15) & fnc $\left(\mathrm{er}^{\mathrm{j}}\right)+{ }_{\text {lex }}\left(\mathrm{v}^{\mathrm{j}} \mathrm{r}^{\mathrm{j}}\right.$ anu: $)$ & PRWDCONL & $\mathrm{EXH}_{\phi}$ \\
\hline a. & $\boldsymbol{\vartheta}_{\phi}\left(\mathrm{er}_{\omega}^{\mathrm{j}}\left(\#^{\prime} \mathrm{v}^{\mathrm{j}} \mathrm{r}^{\mathrm{j}} \mathrm{in}:\right)\right)$ & & * \\
\hline b. & $\phi\left(\omega_{\omega}\left({ }^{\prime} \mathrm{er}^{\mathrm{j}} \ni \# \mathrm{v}^{\mathrm{j}} \mathrm{r}^{\mathrm{j}}\right.\right.$ anu: $\left.)\right)$ & $\operatorname{er}^{j} \ni !$ & \\
\hline c. & ${ }_{\phi}\left({ }_{\omega}\left({ }^{\prime} \operatorname{er}^{\mathrm{j}}{ }_{\omega}\left(\#^{\prime} \mathrm{v}^{\mathrm{j}} \mathrm{r}^{\mathrm{a}}\right.\right.\right.$ au: $\left.\left.)\right)\right)$ & $\mathrm{er}^{j} !$ & \\
\hline
\end{tabular}

In the next section we see when an exception may be made to the usual pattern: the final consonant of clitic often becomes the onset to a vowel-initial host, which introduces the possibility of ${ }_{\omega}$ (Clitic + Host $)$ parsing when the clitic has no other segmental material besides a consonant.

\section{Clitics before vowel-initial stems}

In Irish, vowel-initial stems have the peculiar property that they cause certain preceding consonants to be either velarised or palatalised. Whether a certain vowel-initial stem causes velarisation or palatalisation is unpredictable; it has nothing whatever to do with whether the initial vowel of the stem itself is [+back] or $[-$ back $] .{ }^{8}$ This property may conveniently be thought of as a latent onset consonant that lacks a primary place of articulation and has only [ \pm back] as a secondary place of articulation (Ní Chiosáin 1995a). The 
most straightforward way to test whether the latent onset of a vowel-initial word is [+back] or [-back] is to examine vowel-initial words in the environment of eclipsis.

Eclipsis is one of the two initial mutations found in Irish. Under eclipsis, a voiceless stop or $f$ becomes voiced, a voiced stop becomes the homorganic nasal and a vowel-initial word receives a prothetic $n$. Words that induce eclipses on a following word include go 'that (complementiser)', $i$ 'in' and the plural possessive pronouns ár 'our', bhur 'your' (p1.) and $a$ 'their'. Examples with $a$ 'their' are shown in (16).

(16) Examples of eclipsis (all FP)

\begin{tabular}{|c|c|c|c|}
\hline a. & $\begin{array}{l}\text { pa: } \int \mathrm{t}^{j_{\ni}} \\
\ni \text { ba: } \int_{\mathrm{t}^{\mathrm{j}}}\end{array}$ & $\begin{array}{l}\text { páiste } \\
\text { a bpáiste }\end{array}$ & $\begin{array}{l}\text { 'child' } \\
\text { 'their child' }\end{array}$ \\
\hline b. & $\begin{array}{l}f^{j} \operatorname{aim}^{j} \\
v^{j} \operatorname{aim}^{j}\end{array}$ & $\begin{array}{l}\text { feidhm } \\
\text { a bhfeidhm }\end{array}$ & $\begin{array}{l}\text { 'function' } \\
\text { 'their function }\end{array}$ \\
\hline c. & $\begin{array}{l}\mathrm{d}^{\mathrm{j}} \mathrm{i}: \mathrm{n} \\
\ni \mathrm{n}_{\mathrm{j}} \mathrm{i}: \mathrm{n}\end{array}$ & $\begin{array}{l}\text { dion } \\
\text { a ndion }\end{array}$ & $\begin{array}{l}\text { 'roof' } \\
\text { 'their roof' }\end{array}$ \\
\hline d. & $\begin{array}{l}\mathrm{i}: \mathrm{r}^{j_{\ni}} \\
\ni \mathrm{n}^{\gamma_{1}} \mathrm{r}^{\mathrm{j}_{\ni}}\end{array}$ & $\begin{array}{l}\text { aoire } \\
\text { a n-aoire }\end{array}$ & $\begin{array}{l}\text { 'pastor' } \\
\text { 'their pastor' }\end{array}$ \\
\hline e. & $\begin{array}{l}\text { aspэg } \\
\ni \mathrm{n}^{\mathrm{j}} \text { aspэg }\end{array}$ & $\begin{array}{l}\text { easpag } \\
\text { a n-easpag }\end{array}$ & $\begin{array}{l}\text { 'bishop' } \\
\text { 'their bishop' }\end{array}$ \\
\hline
\end{tabular}

As examples $(16 \mathrm{~d}-\mathrm{e})$ show, the $n$ that appears is velarised before the stem aoire 'pastor' but palatalised before the stem easpag 'bishop'. All vowel-initial stems spread either [+back] or [-back] consistently: whenever aoire spreads, it will spread [+back], and whenever easpag spreads, it will spread [back]. For example, masculine singular nouns in the nominative case take an epenthetic $t$ onset after the definite article an, and the quality of this $t$ is the same as that of the $n$ that appears under eclipsis: [эn

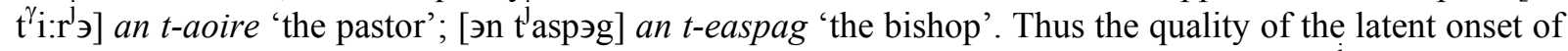
vowel-initial stems is lexically specified: the root for 'pastor' is underlyingly /[+back]i: $\mathrm{r}^{\mathrm{j}} \ni /$ and the root

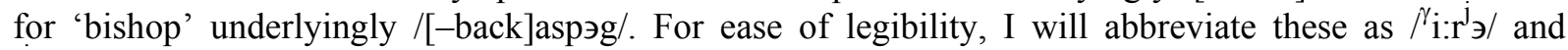
$j_{\text {asp }} \mathrm{g} /$, but it must be made clear that these are not consonant onsets $[\gamma]$ and $[j]$, but rather floating features. Minimal pairs can be distinguished by whether the latent onset is $\gamma^{\gamma} /$ or $\mathrm{H} /$ : úill $\gamma^{\gamma} \mathrm{u}: \mathrm{l}^{\mathrm{j}} /$ ' 'apple' (gen.)

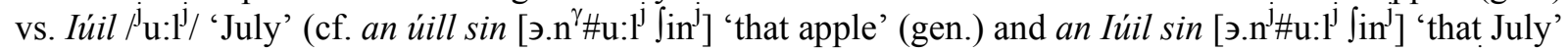
(gen.)). When no appropriate consonant precedes, the words are homophonous: cf. croí úill [kri: u: $\left.\mathrm{l}^{\mathrm{j}}\right]$ 'apple core' beside mi Iúil [ $\left.\mathrm{m}^{\mathrm{j}} \mathrm{i}: \mathrm{u}: \mathrm{i}^{\mathrm{j}}\right]$ 'month of July'.

Similar behaviour is seen in $f$-initial words under lenition. Lenition (the other initial mutation in Irish besides eclipsis) has the effect of changing oral stops and $m$ into fricatives, of changing [s] and [ $]$ ] into [h], and of deleting $f$. When $f$ before a vowel is deleted under lenition, however, its underlying [back] feature (i.e. $[+$ back $]$ in the case of $\left[\mathrm{f}^{\prime} / \mathrm{f}^{\mathrm{W}}\right]$ and $[-$ back $]$ in the case of $\left[\mathrm{f}^{\mathrm{j}}\right]$ ) remains as the latent onset of the now vowel-initial word. The underlying /f/ that has been deleted under lenition is commemorated in the spelling with $f h$, e.g. a fheidhm [э aim ${ }^{\mathrm{j}}$ ' 'his function'.

The spreading of the "floating" [back] feature from the latent onset of a vowel-initial stem (or a lenited $f$-initial stem) onto the final consonant of a preceding morpheme can be used as a diagnostic for resyllabification. Where there is back spreading, there is resyllabification, and where there is no back spreading, there is also no resyllabification.

Whether or not there is resyllabification of a word-final consonant before a following vowel-initial word depends on a variety of grammatical circumstances. First of all, there is no resyllabification between two lexical words, as shown in (17), not even within compounds, as shown in (18). 
(17) No resyllabification between lexical words
a. $\quad / \mathrm{d} \ni+\mathrm{xl}^{\mathrm{j}} \mathrm{in}^{\mathrm{j}}+{ }^{\gamma_{\mathrm{i}}} \mathrm{j}^{\mathrm{j}}{ }_{\text {axi }} / / \quad$ de chlainn Ui Eachaidh
də $\mathrm{xl}^{\mathrm{j}} \mathrm{in}^{\mathrm{j}}$. i ahi 'of the Ó hEachaidh family'
(Ulster: Wagner 1959, 251)
b. /galər ${ }^{\gamma}+{ }^{\mathrm{j}} \mathrm{e}: \mathrm{g}^{\mathrm{j}} \mathrm{j}^{\mathrm{j}} \mathrm{t}^{\mathrm{j}} / \quad$ galar éigint
galэr ${ }^{\gamma}$. e: $\mathrm{g}^{\mathrm{j}} \mathrm{gn}^{\mathrm{j}} \mathrm{t}^{\mathrm{j}} \quad$ 'some disease'

(Munster: Sjoestedt-Jonval 1938, 188)
c. $\quad / \operatorname{lor}^{\gamma} \mathrm{g}^{\gamma}+\mathrm{j}_{\text {ist }} \mathrm{s} / \quad$ (ag) lorg iostas
lorəg ${ }^{\gamma}$. istэs 'looking for lodging'
(Munster: Breatnach 1947, 94)

(18) No resyllabification in compound words

$$
\begin{array}{ll}
\text { /a:rd } \mathrm{rd}^{\gamma}+{ }_{\mathrm{asp}} \ni \mathrm{g} / & \text { ardeaspag } \\
\mathrm{a}: \mathrm{rd}^{\gamma} \cdot \text { aspэg } & \text { 'archbishop' }
\end{array}
$$

The failure of resyllabification after a lexical word indicates a high-ranking alignment constraint on right edges, stated in (19). ${ }^{9}$ The tableau in (20) illustrates the phrase galar éigint [galər ${ }^{\gamma} . \mathrm{e} \mathrm{g}^{\mathrm{j}}{ }^{\mathrm{j}} \mathrm{n}^{\mathrm{j}} \mathrm{j}^{\mathrm{j}}$ ] 'some disease' (17b).

(19) WDCONR (Selkirk 1995)

Align-R(Lex, $\omega)$

The right edge of every lexical word is aligned with the right edge of a pword.

\begin{tabular}{|c|c|c|}
\hline 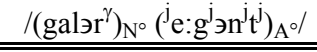 & WDCONR & ONSET \\
\hline $\boldsymbol{v}_{\omega}\left(\right.$ gal’r $\left.r^{\gamma}\right) \#_{\omega}\left(\mathrm{e}: \mathrm{g}^{\mathrm{j}} \ni \mathrm{n}^{\mathrm{j}} \mathrm{t}^{\mathrm{j}}\right)$ & & * \\
\hline 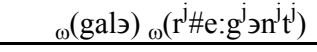 & $* !$ & \\
\hline
\end{tabular}

(20)

Resyllabification and back spreading are seen on many but not all proclitics before vowel-initial stems; as we shall see in the remainder of this section, the behaviour depends partly on the phonological shape of the clitic, and partly on its syntactic structure. ${ }^{10} \mathrm{I}$ begin with vowel-final proclitics before moving on to consonant-final clitics, which undergo resyllabification before a vowel-initial stem unless an intervening trace blocks it.

\subsection{Vowel-final proclitics}

The "floating" [back] feature of a vowel-initial stem shows up on the consonant of a proclitic of the form $\mathrm{Cv}$ (where $\mathrm{v}=$ short vowel), which will undergo elision before a vowel-initial stem. Examples are shown in (21)-(24).

(21) $/ b^{\gamma} \ni / b a$ (copula, past/conditional)
a. $\quad+/ \mathrm{v}^{\mathrm{j}} \mathrm{in}^{\mathrm{j}} \mathrm{F}^{\mathrm{j}} /$ mhinic 'often' $=\left[\mathrm{b}^{\gamma}{ }_{\ni} \# \mathrm{v}^{\mathrm{j}}{ }_{i n}{ }^{\mathrm{j}}{ }^{\mathrm{j}} \mathrm{k}^{\mathrm{j}}\right]$ ba mhinic (de Búrca 1958, 85)
b. $\quad+j^{\mathrm{j}} \mathrm{a}: \mathrm{r} /$ fhearr 'better' $\quad=\left[\mathrm{b}^{\mathrm{j}}\right.$ \#a:r $]$ b'fhearr (Wagner 1959, 245)

(22) $/ \mathrm{m}^{\gamma} \ni / m o$ (determiner) 'my'

a. $+/ \mathrm{v}^{\mathrm{j}}$ an/ bhean 'wife' $=\left[\mathrm{m}^{\gamma}{ }^{\gamma} \# \mathrm{v}^{\mathrm{j}}\right.$ an $]$ mo bhean 
(Hamilton 1974, 26)

b. $\quad+/^{\gamma}$ ai / aghaidh 'face' $=\left[\mathrm{m}^{\gamma}\right.$ \#ai $]$ m'aghaidh

(Holmer 1962, 91)

c. $\quad+\mu^{\mathrm{j}} \mathrm{e}: \mathrm{d} \ni \mathrm{n} /$ éadan 'face' $=\left[\mathrm{m}^{\mathrm{j}}\right.$ \#e:dэn $]$ m'éadan

(de Bhaldraithe 1953, 154)

(23) $/ \mathrm{d}^{\gamma} \ni / d o$ (preterite tense marker)
a. + /hol ${ }^{\mathrm{j}} \mathrm{g}^{\mathrm{j}} /$ thoiligh 'consent' $=\left[\mathrm{d}^{\mathrm{\gamma}} \ni \# \mathrm{hol}^{\mathrm{j}} \ni \mathrm{g}^{\mathrm{j}}\right]$
do thoiligh ${ }^{11}$
(Munster: Ó Cuív 1944, 87)
b. $\quad+{ }^{\gamma} \supset: 1 /$ '́l 'drink'
(Ulster: Hughes 1986, 242)
$=\left[\mathrm{d}^{\gamma} \# \supset: 1\right] d$ 'ól
c. $\quad+\mu^{\mathrm{j}}: \mathrm{r}^{\mathrm{j}} \mathrm{i}$ / éirigh 'rise' $\quad=\left[\mathrm{d}^{\mathrm{j}} \# \mathrm{e}: \mathrm{r}^{\mathrm{j}} \mathrm{i}\right.$ : $]$ d'éirigh
(Connacht: Mhac an Fhailigh 1968, 111)

(24) $/ \mathrm{d}^{\mathrm{j}} \mathrm{e} / d e$ 'of'

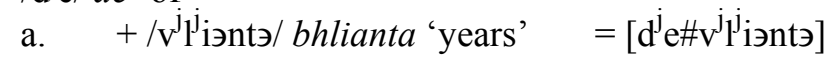
de bhlianta (Munster: Breatnach 1947, 95)
b. $+\mu^{\gamma} \mathrm{i}:$ çə/ oíche 'night' $=\left[\mathrm{d}^{\gamma} \# \mathrm{i}\right.$ :çэ $]$ d'oíche
(Munster: Breatnach 1947, 99)

Proclitics that end in long vowels, however, show no elision before vowel-initial stems. In this case the latent onset of the stem is not realised.

(25) No elision of full vowels
a. Na:hər/
$\left[\mathrm{n}^{\mathrm{j}} \mathrm{i}: \mathrm{a}: \mathrm{h} \ni \mathrm{r}\right]$
ni fhaighthear
'one does not get'
(Connacht: de Búrca 1958, 88)
b. $\quad \mathrm{j}_{\mathrm{i}: \mathrm{n}}^{\mathrm{j}} \int_{\ni \mathrm{n} /}$
[m: i:n ${ }^{\mathrm{j}} \int_{\ni n}$ tu: $]$
má insionn tú
'if you tell' (Munster: Sjoestedt-Jonval 1938, 192)

These data may be analysed as follows. In most $\mathrm{Cv}$ proclitics that appear before vowel-initial stems the vowel of the clitic is [э], which may be thought of as being placeless. ${ }^{2}$ When a short vowel at the end of a function word is elided, the remaining consonant is syllabified as the onset of the pword of the host.

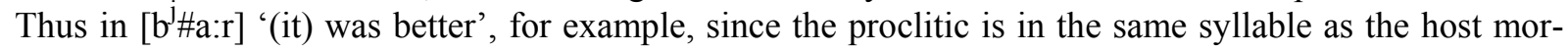
pheme, the two must necessarily be within the same pword. The structure is therefore ${ }_{\omega}(\mathrm{Clitic}+\mathrm{Host})$, an internal clitic. In other words, while the free clitic analysis is typical in Irish, as we saw above, the internal clitic option is available in order to avoid hiatus after a short vowel. In OT terms, vowel hiatus is a violation of both the general ONSET constraint stated in (26) and the more specific NOHIATUS constraint stated in (27).

\section{(26) ONSET}

Syllables have onsets.

\section{(27) NoHiatus}

A V.V sequence is prohibited.

The status of the constraint NoHiATUS has been somewhat controversial: McCarthy \& Prince (1993), for example, argue specifically against such a constraint. Nevertheless, we shall see in the course of this 
paper that NOHIATUS is a necessary constraint in Irish; its effects cannot be achieved by combining ONSET with an alignment constraint, as they can in Axininca Campa under McCarthy \& Prince's analysis. For now, I will assume NOHIATUS to be the relevant constraint; later I will show that it crucially outranks ONSET in Irish. ${ }^{13}$

The facts of (21)-(25) can be explained by postulating that NOHIATUS outranks both PRWDCONL (the constraint requiring a lexical word to begin crisply at a pword edge) and MAX-э (requiring an underlying placeless vowel to be present in the output). This ranking permits deletion of a placeless vowel as well as word misalignment in order to avoid hiatus. ${ }^{14}$

\begin{tabular}{|c|c|c|c|}
\hline$/\left(\mathrm{b}^{\gamma}\right)_{\mathrm{fnc}}\left({ }^{\mathrm{j} a: r}\right)_{\mathrm{lex}}$ & $\begin{array}{l}\text { NoHiatus } \\
\end{array}$ & \begin{tabular}{|l|l} 
PRWCONL \\
\end{tabular} & MAX-э \\
\hline $\mathrm{b}^{\gamma_{\ni} \#_{\omega}(\mathrm{a}: \mathrm{r})}$ & $* !$ & & \\
\hline $\boldsymbol{v}_{\omega}\left(\mathrm{b}^{\mathrm{j} \# \mathrm{a}: \mathrm{r})}\right.$ & & * & * \\
\hline
\end{tabular}

MAX-FULLVOWEL, however, which requires an underlying vowel with full place specification (including all long vowels in Irish) to be present in the output, outranks NOHIATUS, as shown in (29).

(29)

\begin{tabular}{|r||c|c|c|}
\hline$/\left(\mathrm{m}^{\gamma} \mathrm{a}:\right)_{\text {fnc }}\left({ }^{\mathrm{i}}: \mathrm{n}^{\mathrm{j}} \int_{\ni n}\right)_{\text {lex }} /$ & MAX-FV & NoHiatus & PRWDCONL \\
\hline \hline $\boldsymbol{\gamma} \mathrm{m}^{\gamma} \mathrm{a}: \#{ }_{\omega}\left(\mathrm{i}: \mathrm{n}^{\mathrm{j}} \int_{\ni n}\right)$ & & $*$ & \\
\hline$\omega_{\omega}\left(\mathrm{m}^{\mathrm{j}} \# \mathrm{i}: \mathrm{n} \int_{\ni n}\right)$ & $* !$ & & $*$ \\
\hline
\end{tabular}

Because short vowels are placeless in vowel-final proclitics in Irish, they can be elided before vowelinitial stems, and the consonant of the proclitic incorporated into the pword of the host. Thus under these circumstances the internal clitic structure ${ }_{\omega}($ Clitic + Host $)$ rather than the usual free clitic structure ${ }_{\phi}(\mathrm{Clitic}$ ${ }_{\omega}($ Host $\left.)\right)$ can be found in Irish, indicating that a single language need not be committed to a single clitic structure to the absolute exclusion of other patterns. In the case of consonant-final proclitics, we shall see that a morpheme can even be split across a phonological boundary, subject to syntactically based restrictions.

\subsection{Consonant-final proclitics}

With proclitics that underlyingly end in consonants, the picture is more complicated than with vowel-final proclitics. In some instances, the final consonant will undergo resyllabification (and the concomitant back spreading) before vowel-initial stems; in other instances there is no resyllabification. In this subsection I examine the differing behaviour of consonant-final proclitics before vowel-initial stems and argue that resyllabification between a proclitic and stem is blocked if a trace intervenes. If there is no trace between the proclitic and the stem, there is resyllabification. ${ }^{15}$

The consonant-final clitics that undergo resyllabification include the determiners an 'the' and aon 'any, one' (also gach aon 'every'), the pre-sentential question particle an before a verb or pronominal augment, the progressive aspect marker $a g$, the present copula is before a pronominal augment and a variety of copular forms ending in orthographic $-r b$ and $-r b h$. Before vowel-initial stems (and lenited $f$-initial stems), the final consonant of these clitics is resyllabified as the onset of the host word, and the quality of the final consonant matches that of the latent onset of the following stem.

(30) Resyllabification between determiner and noun
a. $\quad / \ni n^{\gamma}+{ }^{\mathrm{j}} \mathrm{i}: \mathrm{r}^{\mathrm{j}} \mathrm{n}^{\mathrm{j}}{ }^{\mathrm{j}} \ni /$
э. $n^{\mathrm{j}} \# \mathrm{i}: \mathrm{r}^{\mathrm{j}} \mathrm{n}^{\mathrm{j}} \mathrm{j}_{\ni}$
an fhirinne
(Ulster: Hamilton 1974, 30)
the truth
'the truth' 

b. /e:n ${ }^{\gamma}+{ }^{j}$ u:ntэs/

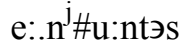
aon iontas
(Munster: Sjoestedt 1931, 156)
any wonder
'any wonder'
c. /gэhe: $\mathrm{n}^{\gamma}+{ }^{\mathrm{j}} \mathrm{ar} /$
gэhe:.n $n^{\mathrm{j}}$ \#ar
(Munster: Breatnach 1947, 75)
gach.aon fhear
every man
'every man'

(31) Resyllabification between the question particle and a verb or pronominal augment
a. $\quad /$ n $^{\gamma}+{ }^{\mathrm{j}} \mathrm{i}: \mathrm{n}^{\mathrm{j}} \int_{\mathrm{o}: \mathrm{x} /}$
э. $\mathrm{n}^{\mathrm{j}} \# \mathrm{i}: \mathrm{n}^{\mathrm{j}} \int_{0: \mathrm{x}}$
an inseodh?
Q tell.COND
'would (s/he) tell?'

(Connacht: de Bhaldraithe 1953, 234)
b. $\quad /$ эn $^{\gamma}+{ }^{\mathrm{j}} \mathrm{i}:+\int \mathrm{in}^{\mathrm{j}}+\operatorname{ma}: \mathrm{r}^{\mathrm{j}}{ }_{\ni}$
э. j $^{\mathrm{j}}+\mathrm{j}_{\mathrm{i}} \int_{\mathrm{in}}^{\mathrm{j}} \mathrm{ma}: \mathrm{r}_{\ni}{ }_{\ni}$
(Ó Baoill 1986, 38)
an $i \quad$ sin Máire?
Q FEM.SG that
'is that Máire?'

(32) Resyllabification after the progressive aspect marker $a g$
a. $\quad$ ’g $+{ }^{\gamma}$ osk ${ }^{\mathrm{j}} \mathrm{l}_{\mathrm{i}}^{\mathrm{j}} /$

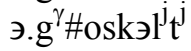
ag oscailt
(Breatnach 1947, 100)
PROG Open.NONFIN
'opening'
b. $/ \ni g .+{ }^{j_{i s k}{ }^{j}}{ }^{j}$ axt/
э. $\mathrm{g}^{\mathrm{j}}$ \#iskэr ${ }^{\mathrm{j}}$ arht
(Ulster: Hamilton 1974, 28)
ag iascaireacht
PROG fish.NONFIN
'fishing'

(33) Resyllabification between the present copula is and a pronominal augment ${ }^{16}$

a. $\quad / \mathrm{k}_{\mathrm{j}}^{\mathrm{j}} \mathrm{e}: 1+$ ro: + hrom + is $+{ }_{\mathrm{a}}^{\mathrm{j}}+{ }^{\mathrm{j}} \mathrm{e}:+\int_{\mathrm{o}} /$

$\int \mathrm{k}_{\mathrm{j}}^{\mathrm{e}}: 1$ ro: hrom i. $\int \# \mathrm{a}$ e: $\int_{\mathrm{o}}$ scéal róthrom is ea é.seo

story too.heavy COP DUMMY this

(Munster: Ó Cuív 1944, 95)

'a too-heavy story this is'

b. /agəs + is $+{ }^{\mathrm{j}} \mathrm{e}:+{ }+\mathrm{v}^{\mathrm{j}} \mathrm{i}:+\mathrm{ti}_{\mathrm{i}} \mathrm{j}^{\mathrm{j}} \mathrm{t}_{\ni}+\jmath^{\mathrm{j}} \mathrm{k}^{\mathrm{j}} \mathrm{i} /$

agəs i. $\int \# \mathrm{e}: \mathrm{v}^{\mathrm{j}} \mathrm{i}$ : $\mathrm{ti}: \mathrm{l}^{\mathrm{j}} \mathrm{t}^{\mathrm{j}} \mathrm{k}^{\mathrm{j}} \mathrm{k}_{\mathrm{i}}$ agus is é a bhi tuillte aici

and COP it aL was deserved by.her

'and it's what she deserved'

(Munster: Sjoestedt-Jonval 1938, 192)

(34) Resyllabification after copula forms in $-r b(h)^{17}$
a. / / rb $+{ }^{\mathrm{j}} \mathrm{o}: 1+\mathrm{do}: /$
эr. $\mathrm{b}^{\mathrm{j}} \# \mathrm{o}: 1 \mathrm{do}$ :
(Ó Baoill 1986, 39)
arb eol dó
aN.COP.PRES known to.him 'who knows'
b. /gэrb $+\gamma_{\text {aul } / /}$ gər.b ${ }^{\gamma}$ \#aulэ
gurb amhlaidh
that.COP.PRES thus
'that it is thus'

(Connacht: de Bhaldraithe 1953, 95)
c. /gərv $+{ }^{\mathrm{j}_{\mathrm{i}}: \mathrm{r} /}$
gər. $v^{\mathrm{j}} \# \mathrm{i}: \mathrm{r}$
gurbh fhior
that.COP.PAST true
(Munster: Ó Cuív 1944, 93)
'that it was true'




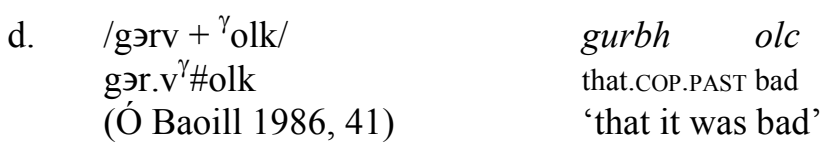

The fact that there is no epenthesis between the $[\mathrm{r}]$ and the $[\mathrm{b} / \mathrm{v}]$ in forms like (34) indicates that, in spite of the orthography, there is a pword boundary at this point: $\left.\phi_{(\mathrm{g} \ni \mathrm{r}}\left(\mathrm{v}^{\gamma} \# \mathrm{\# i} \mathrm{r}\right)\right)$ : $\mathrm{cf} . \S 2.2$.

There is no resyllabification with the present copula is and the question particle an in copular sentences, where the copula itself does not surface. As seen above, however, is and an do resyllabify before pronominal augments.

(35) No resyllabification with is

/is $+{ }^{\mathrm{j}} \supset: 1 \mathrm{du} /$

is eol domh

is\#.つ: $1 \mathrm{du}$

COP known to.me

(Ulster: Ó Searcaigh 1925, 148)

'I know'

(36) No resyllabification with the question particle before a null copula
$/ \ni n^{\gamma}+{ }^{j_{i \ni s k}}+\mathrm{d}^{\mathrm{j}}$ as $+\mathrm{e}: /$
an iasc deas é?
$\ni^{\gamma} \#$.iэsk d as e:
(Ó Baoill 1986, 38)
Q fish nice it
'is it nice fish?'

The difference between the resyllabifying and non-resyllabifying type of clitic structure seems to be a syntactic difference. If we examine the syntactic trees for the resyllabifying type in (30)-(34), we see that in every case, the proclitic and the host stem are immediately adjacent in the syntactic tree. The structure of the copular sentences shown in (40)-(42) will be discussed in $\S 4 .^{18}$

(37) Structure of (30)

a. an fhirinne 'the truth'

DP

an fhírinne

b. aon iontas 'any wonder'

DP

$\overbrace{\text { aon iontas }}^{\mathrm{NP}}$

c. gach aon fhear 'every man'

DP

$\overbrace{\mathrm{D}^{\circ}}^{\mathrm{NP}}$ 
(38) Structure of (31)

a. $\quad$ an inseodh (Q tell-COND) 'would (s/he) tell?'

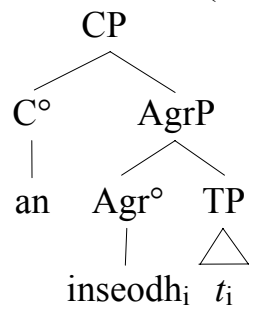

b. $\quad$ an i sin Máire (Q FEM that Máire) 'is that Máire?'

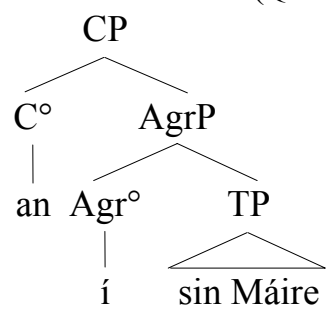

(39) Structure of (32a): ag oscailt (PROG open-NONFIN) 'opening'

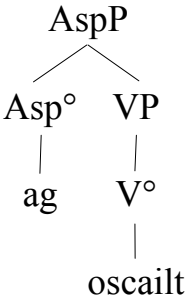

(40) Structure of (33a): scéal róthrom is ea é.seo (story too.heavy COP DUMMY this) 'a too-heavy story this is'

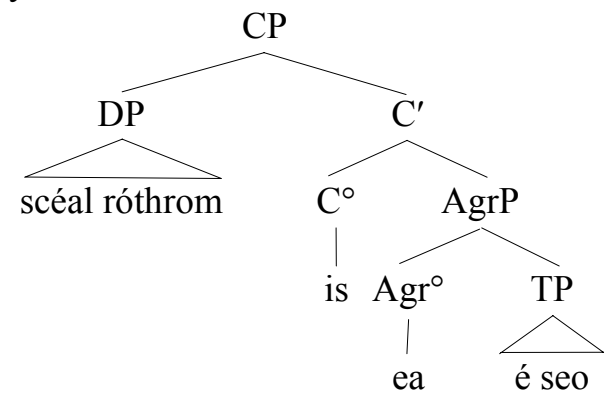

(41) Structure of (34a): arb eol dó (aN.COP.PRES known to.him) 'who knows'

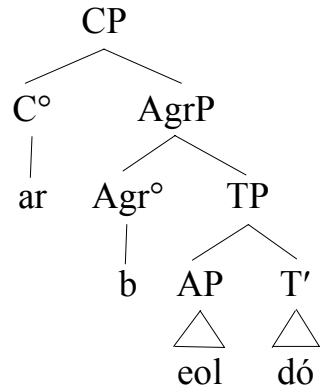


(42) Structure of (34c): gurbh fhior (that.COP.PAST true) 'that it was true'

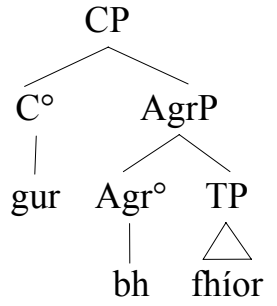

But in the non-resyllabifying constructions of (35)-(36), the trace of the copular features that have moved from $\mathrm{Agr}^{\circ}$ to $\mathrm{C}^{\circ}$ (see $\S 4$ ) intervenes between the proclitic and the host, as shown in (43)-(44).

(43) Structure of (35): is eol domh (COP known to.me) 'I know'

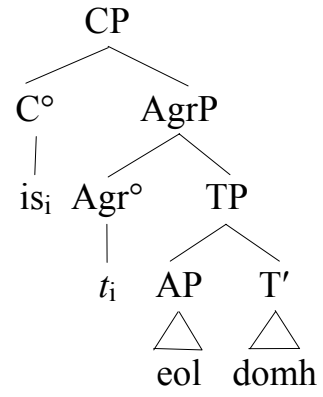

(44) Structure of (36): an iasc deas é? (Q fish nice it) 'is it nice fish?'

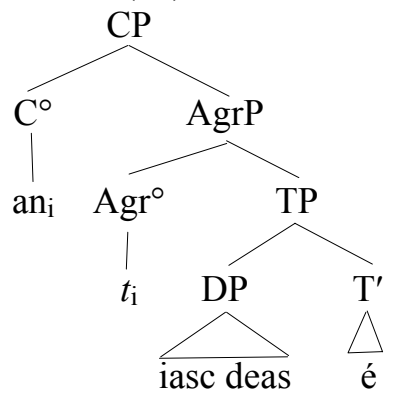

The blocking of a phonological process across a trace is well known cross-linguistically (cf. Rotenberg 1978, Selkirk 1984 and others), e.g. in English, where want to can contract to wanna only if no wh-trace intervenes between the two words: I wanna win the race but * Who do you wanna win the race? for Who $\mathrm{i}$ do you want $\mathrm{t}_{\mathrm{i}}$ to win the race? Similarly, in Irish, traces block resyllabification after a proclitic. This effect can be attributed to an alignment constraint like that in (45):

\section{(45) ALign-Trace}

Align(trace, R; pword, L)

The right edge of every trace corresponds to the left edge of a pword.

This constraint, which requires a trace to be immediately followed by the beginning of a pword, can be seen as a way of acoustically enhancing the presence of an element that has no phonological content of its own.

The resyllabification in (37)-(42) can be accounted for by postulating that ONSET outranks 
PRWDCONL in Irish, which will achieve the effect of resyllabification before a vowel-initial word. This is demonstrated in the tableau in (46) for the phrase an fhirinne [э.n ${ }^{\mathrm{j}} \# \mathrm{i}: \mathrm{r}^{\mathrm{j}} \mathrm{n}^{\mathrm{j}} \ni$ ] 'the truth' (30a).

(46)

\begin{tabular}{|c|c|c|}
\hline$/\left({ }^{\prime} n^{\gamma}\right)_{D^{\circ}}\left({ }^{\mathrm{j}} \mathrm{i}_{\mathrm{r}} \mathrm{r}^{\mathrm{j}} \mathrm{n}^{\mathrm{j}} \ni\right)_{\mathrm{N}^{\circ}} /$ & ONSET & PRWDCONL \\
\hline${ } \mathrm{n}^{\gamma} \#_{\omega}\left(\mathrm{i}: \mathrm{r}^{\mathrm{j}} \ni n^{j} \ni\right)$ & *! & \\
\hline 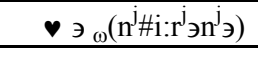 & & * \\
\hline
\end{tabular}

The addition of ALIGN-TRACE above ONSET accounts for the failure of resyllabification where a trace intervenes between a function word and a lexical word, as shown in (47) for is eol [is\#.つ:1] from (43).

(47)

\begin{tabular}{|r||c|c|c|}
\hline $\begin{array}{r}/(\mathrm{is})_{\mathrm{C}^{\circ}} t_{\mathrm{Agr}^{\circ}} \\
(\supset \supset: 1)_{\mathrm{A}^{\circ}} /\end{array}$ & ALIGN-TRACE & ONSET & PRWDCoNL \\
\hline \hline $\boldsymbol{\vee}$ is $t_{\omega}(\supset: 1)$ & & $*$ & \\
\hline $\mathrm{i}_{\omega}(1 t \supset: \mathrm{l})$ & $* !$ & & $*$ \\
\hline
\end{tabular}

If there are two adjacent traces in a string, as there are between eol and domh in (43), or if a trace is sentence-final, as in (38a), there is no insertion of an entire pword to enforce ALIGN-TRACE compliance. This can be attributed to a high-ranking constraint against pword epenthesis (DEP- $\omega)$, as shown in (48).

(48) No pword epenthesis

a.

\begin{tabular}{|c|c|c|}
\hline $\begin{array}{r}/\left({ }^{\mathrm{j}} \supset: 1\right)_{\mathrm{A}^{\circ}} t_{\mathrm{T}^{\circ}} t_{\mathrm{AP}} \\
(\mathrm{du})_{\mathrm{P}^{\circ}+\mathrm{D}^{\circ}}\end{array}$ & DEP- $\omega$ & ALIGN-TRACE \\
\hline$\supset: 1 t_{\mathrm{T}^{\circ} \omega}(\mathrm{ta}) t_{\mathrm{AP} \omega}(\mathrm{du})$ & $* !$ & \\
\hline $\boldsymbol{\vee} \supset: 1 t_{\mathrm{T}^{\circ}} t_{\mathrm{AP} \omega}(\mathrm{du})$ & & $t_{\mathrm{T}^{\circ}}$ \\
\hline
\end{tabular}

b.

\begin{tabular}{|c|c|c|}
\hline$/(\ni n)_{\mathrm{C}^{\circ}}\left({ }^{\mathrm{j}} \mathrm{iùu}^{\mathrm{j}} \int_{\mathrm{o}: \mathrm{x}}\right)_{\mathrm{Agr}^{\circ}} t_{\mathrm{V}^{\circ}}$ & DEP- $\omega$ & AligN-TRACE \\
\hline$\exists_{\omega}\left(\mathrm{n}^{\mathrm{j}} \mathrm{i}: \mathrm{n}^{\mathrm{i}} \mathrm{\rho}_{\mathrm{o}} \mathrm{x}\right) t_{\omega}(\mathrm{ta})$ & $* !$ & \\
\hline • ${ }_{\mathrm{w}}\left(\mathrm{n}^{\mathrm{j}} \mathrm{i}: \mathrm{n}^{\mathrm{j}} \mathrm{o}_{\mathrm{o}: \mathrm{x}} t\right.$ & & $i$ \\
\hline
\end{tabular}

To return to the case of vowel-final proclitics, when we examine the syntactic structure of a phrase like b'fhearr [ $\left.\mathrm{b}^{\mathrm{j}} \mathrm{a}: \mathrm{r}\right]$ (COP.COND better) 'it would be better' (21b), we see that a trace is present between $b a$ and fhearr.

(49)

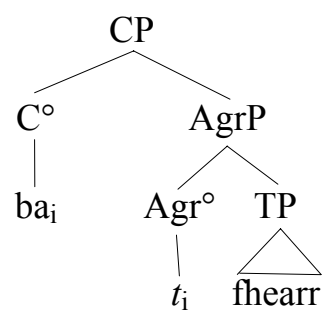

The ranking ALIGN-TRACE » ONSET predicts a surface $*\left[b^{\gamma}\right.$ э.a:r $]$ rather than $\left[b^{j} a: r\right]$. But $*\left[b^{\gamma}\right.$ э.a:r $]$, unlike [is.つ:l du], is not only an ONSET violation, but a NOHIATUS violation as well. Thus we see that NOHIATUS is indeed a separate constraint from ONSET, and in Irish the two are crucially ranked on either side of ALIGN-TRACE, as shown in the tableau in (50).

(50)

\begin{tabular}{|r||c|c|c|}
\hline$/\left(\mathrm{b}^{\gamma} \ni\right)_{\mathrm{Agr}}{ }_{\mathrm{T}^{\circ}}\left({ }_{\mathrm{a}}^{\mathrm{a}: \mathrm{r})_{\mathrm{A}^{\circ}}}\right.$ & NOHIATUS & ALIGN-TRACE & ONSET \\
\hline \hline $\mathrm{b}^{\gamma} \ni t_{\omega}(\mathrm{a}: \mathrm{r})$ & $* !$ & & $*$ \\
\hline
\end{tabular}




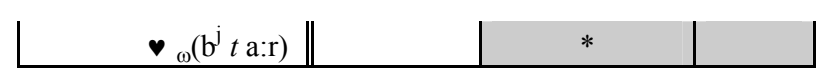

We have now seen how ONSET drives resyllabification between a proclitic and a syntactically immediately adjacent host in Irish. Higher ranking ALIGN-TRACE however prevents resyllabification across a trace or unfilled head position; yet ALIGN-TRACE itself may be violated in order to avoid hiatus. In the next subsection I show how ALIGN-TRACE prevents syllabification of a stray consonant into an onset cluster.

\subsection{Aphaeresis in is}

In $\S 2.3$ above I argued that the aphaeretic form [s $\left.\sim \int\right]$ of the copula is remains external to the prosodic word of the host. The evidence included the fact that voiceless stops after the aphaeretic copula remain aspirated, as in word-initial position, and that $s f$ - clusters, which are virtually unknown in word-initial position, arise through aphaeresis as well. The data in (12) are repeated here for convenience.

(51) Aphaeretic copula + host sequences
a. $\phi\left(\int \#_{\omega}\left(\mathrm{t}^{\mathrm{jh}} \mathrm{O}:\right)\right)$
b. $\quad \phi\left(\mathbb{H}_{\omega}\left(\mathrm{k}^{\mathrm{jh}}\right.\right.$ art $\left.)\right) \sim \phi\left(\mathrm{s} \#_{\omega}\left(\mathrm{k}^{\mathrm{jh}}\right.\right.$ art $\left.)\right)$
is teo '(it) is hotter'
c. $\phi\left(\mathrm{s} \#_{\omega}(\mathrm{f} a: r)\right)$
is ceart
'(it) is right'
is fearr
'(it) is better'

In (33) above we saw that the full form of the copula is undergoes resyllabification only before one of the pronominal augments é $i$ ea iad. Aphaeresis is also possible here; in fact, aphaeretic pronunciations

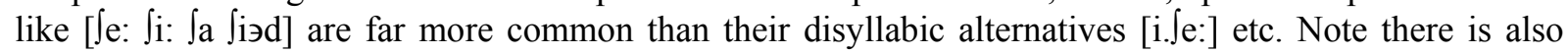
back spreading from a following [-back] latent onset of a pronominal augment. When the aphaeretic copula precedes anything besides a pronominal augment, there is no back spreading, as shown in (52). ${ }^{19}$

$$
\begin{array}{ll}
/ \mathrm{s}+{ }^{\mathrm{j}} \mathrm{um}^{\mathrm{w}} \mathrm{i}: / & \text { is iomai } \\
\mathrm{s} \# \mathrm{um}^{\mathrm{w}} \mathrm{i}: & \text { '(it) is many' }
\end{array}
$$

(Connacht: de Búrca 1958, 86)

I therefore propose that the aphaeretic form of the copula is external to the prosodic word, and therefore of necessity external to the initial syllable of a following lexical word. In this case the consonant $s$ is extrasyllabic, and linked directly to the $\phi$ node. But before a pronominal augment, the $s$ is syllabified as the onset and becomes []] under the influence of the latent [-back] onset. As seen above in (40), is is immediately adjacent in the tree to a following pronominal augment, while as shown in (43) a sequence of is + lexical word is divided by a trace in Agr ${ }^{\circ}$. The constraint ALIGN-TRACE can therefore be called upon not only to prevent resyllabification in is eol domh [is\#.つ:1 du] but also to prevent an intrasyllabic affiliation in aphaeretic is iomai $\left[\mathrm{s} \# . \mathrm{um}^{\mathrm{w}} \mathrm{i}\right.$ :]. No new constraints or rankings are needed to show this: the ranking ALIGN-TRACE » ONSET was shown in (47), the ranking ONSET » PRWDCONL in (46), and the ranking $\mathrm{PRWDCONL} \gg \mathrm{EXH}_{\phi}$ in (15).

\begin{tabular}{|r||c|c|c|c|}
\hline$\left./(\mathrm{s})_{\text {Agr }^{\circ}} t_{\mathrm{T}^{\circ}}\left({ }^{\mathrm{j}} \mathrm{um}^{\mathrm{w}}{ }^{\mathrm{i}:}\right)_{\mathrm{A}^{\circ}}\right)$ & ALIGN-TRACE & ONSET & PRWDCONL & EXH $_{\phi}$ \\
\hline $\boldsymbol{v}_{\phi}\left(\mathrm{s}_{\omega}\left(\mathrm{um}^{\mathrm{w}} \mathrm{i}:\right)\right)$ & & $*$ & & $*$ \\
\hline$\left.\phi\left(\omega, \mathrm{um}^{\mathrm{i}} \mathrm{i}:\right)\right)$ & $* !$ & & $*$ & \\
\hline
\end{tabular}

The aphaeretic copula is extrasyllabic also before a consonant-initial lexical word like ceart (cf. (51b)), in which case ONSET is irrelevant. 
(54)

\begin{tabular}{|r||c|c|c|c|}
\hline$/(\mathrm{s})_{\text {Agro }^{\circ}} t_{\mathrm{T}^{\circ}}\left(\mathrm{k}^{\mathrm{j}} \text { art }\right)_{\mathrm{A}^{\circ}} /$ & ALIGN-TRACE & ONSET & PRWDCONL & ExH $_{\phi}$ \\
\hline \hline $\boldsymbol{\vee}_{\phi}\left(\mathrm{s} t_{\omega}\left(\mathrm{k}^{\mathrm{jh}}\right.\right.$ art $\left.)\right)$ & & & & $*$ \\
\hline$\phi_{\phi}\left({ }_{\omega}\left(t \mathrm{k}^{\mathrm{j}}\right.\right.$ art $\left.)\right)$ & $* !$ & & $*$ & \\
\hline
\end{tabular}

But with pronominal augments, where there is no trace separating the copula from the following morpheme, the aphaeretic copula is intrasyllabic in order to avoid an ONSET violation. (A PRWDCONL violation is inevitable since neither the copula nor the pronominal augment is a lexical word.) A copula plus pronominal augment sequence can stand alone as an utterance as the answer to a question. A tableau for (55b), the response to (55a), is shown in (56).

(55) a. An é an fear sin d'athair? b. Is é [ $[\mathrm{e}:]$.

'Is that man your father?'

'Yes.'

(56)

\begin{tabular}{|r||c|c|c|c|}
\hline$/(\mathrm{s})_{\mathrm{C}^{\circ}}+(\mathrm{e}:)_{\mathrm{Agr}^{\circ}}$ & ALIGN-TRACE & ONSET & PRWDCONL & EXH $_{\phi}$ \\
\hline \hline$\phi_{\phi}\left(\mathrm{s}_{\omega}(\mathrm{e}:)\right)$ & & $* !$ & $*$ & $*$ \\
\hline $\boldsymbol{\vee}_{\phi}\left(\omega_{\omega}(\mathrm{e}:)\right)$ & & & $*$ & \\
\hline
\end{tabular}

Thus we see that the aphaeretic form of the copula, which phonologically consists of nothing more than a single consonant, remains outside of the pword of its prosodic host in order not to conceal the presence of a trace. Before a pronominal augment, where no trace is present, the aphaeretic copula is a syllable onset.

In this section I have shown that the internal clitic structure is employed in Irish in cases like b'fhearr [b $\left.\mathrm{b}^{\mathrm{j}} \mathrm{a} \mathrm{r}\right]$ 'it would be better' in order to avoid hiatus. Thus we have further evidence in favour of Hall's (1999) claim that both the free clitic structure and the internal clitic structure can be attested in the same language.

An important further component of the analysis is that in the case of resyllabifying proclitics, a clitic morpheme may be only partially incorporated into the pword of the host. Thus in a structure like an fhirinne $\left[{ }_{\omega}\left(\mathrm{n}^{\mathrm{j}} \# \mathrm{i}: \mathrm{r}^{\mathrm{j}_{\ni}} \mathrm{n}^{\mathrm{j}} \ni\right)\right]$ 'the truth', the pword does not consist exclusively of whole morphemes. Rather, the phonological content of the functional morpheme is partly outside of the pword and partly inside it. The behaviour of resyllabifying proclitics in Irish lends support to Peperkamp's (1997) claim that it is possible for pwords to consist of morphologically arbitrary strings.

In this section I have made several assumptions about the syntactic structure of copular sentences in Irish, which I will motivate in what follows.

\section{Copular sentences}

\subsection{Simple copular forms before lexical words}

The copula of Irish has offered an interesting field of research to syntacticians. Traditionally classified as a defective verb (e.g. in Christian Brothers 1994), the copula has wildly different properties from true verbs: the subject of the copula comes at the end of the sentence (not immediately after the verb, as is typically the case in Irish) in classificatory sentences, and a subject pronoun is in accusative rather than nominative case. In recent work, Carnie (1995) and Doherty (1996a, 1996b) have shown that the copula is a functional element, either a $\mathrm{C}^{\circ}$ or an $\mathrm{I}^{\circ}$. Carnie argues in favour of the $\mathrm{C}^{\circ}$ hypothesis, pointing out that in contrast to true verbs, the copula cannot co-occur with complementisers such as the negative particle $n i$ : 
(57) a. Is amadán é.

COP fool him

'He is a fool.'

b. Ní amadán é.

NEG fool him

'He is not a fool.'

c. *Ní is amadán é.

Under Carnie's analysis, the predicate of the copula moves to $\mathrm{I}^{\circ}$ and thus behaves exactly like an inflected verb in a non-copular sentence, such as $[N i]_{\mathrm{C}^{\circ}}[\text { ritheann }]_{\mathrm{I}^{\circ}}$ sé (NEG run.PRES he) 'He doesn't run'. But there are problems with Carnie's analysis, most notably that the predicate of a copula can be an entire $\mathrm{DP}$, which means he is required to give up the convention that maximal projections cannot move into $\mathrm{X}^{\circ}$ positions. In example (58), the predicate is a DP that includes a relative phrase, which Carnie argues has moved into $\mathrm{I}^{\circ}$.

(58) Is [amhrán a bhuailfidh an píobaire $]_{\mathrm{I}}$ "Yellow Submarine".

COP song aL play.Fut the bagpiper

"'Yellow Submarine" is a song which the bagpiper is going to play.'

Also, the fact that the question particle undergoes resyllabification before a verb (e.g. an inseodh [э. $\left.{ }^{\mathrm{j}_{\mathrm{in}} \mathrm{j}} \int_{\mathrm{o}} \mathrm{x}\right]$ (31a)) but not before a predicate (e.g. an. iasc [эn.iэsk] deas é (36)) strongly suggests a difference in syntactic structure, contrary to Carnie's claim.

Doherty (1996a), on the other hand, argues that the copula is an $I^{\circ}$, that its predicate is its complement under I', and the subject is a right-specifier of IP. Doherty explicitly suggests, however, that IP in Irish is actually divided into AgrP dominating TP. Thus more specifically, the tense features of the copula have moved from $\mathrm{T}^{\circ}$ to $\mathrm{Agr}^{\circ}$, where the tense and agreement features merge to form the morpheme is. Thus the structure of sentence (58) would be:

(59) $\left[\left[\left[\mathrm{Is}_{\mathrm{i}}\right]_{\mathrm{Agr}}\left[t_{\mathrm{i}}\right]_{\mathrm{T}^{\circ}}[\text { amhrán a bhuailfidh an píobaire }]_{\mathrm{DP}}\right]_{\mathrm{I}^{\prime}} \text { "Yellow Submarine". }\right]_{\mathrm{IP}}$

This analysis, however, leaves unexplained the non-occurrence of the copula after ní, as shown in (57), and it also depends on the presence of right-specifiers, which Kayne (1994) argues not to exist. Doherty (1996b) remedies these faults by proposing that although the copula is base generated as a combination of Agr and $\mathrm{T}$ features, all the features move to $\mathrm{C}^{\circ}$ in the surface structure (in contrast to Carnie, who assumes the copula to be generated as a $\mathrm{C}^{\circ}$ ). The predicate is then found in the Spec of TP, having moved there from the predicate position of a small clause. The subject of the small clause remains in situ, as shown in (60).

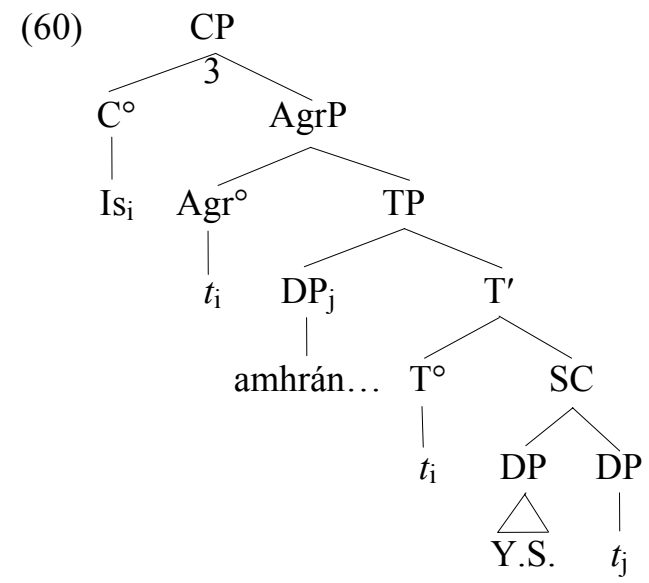


This type of structure, which requires neither phrase-to-head movement nor right-specifiers and which correctly predicts the complementary distribution of $i s$ and other complementisers, is the one I have been assuming in this paper. The trace in $\mathrm{Agr}^{\circ}$ is crucial to my argument, as only the presence of that trace predicts that resyllabification between is and the first word of the predicate is blocked (cf. (43)).

\subsection{Copular forms before pronominal augments}

In identificational copular sentences in Irish, the word order is copula + subject + predicate; the copula and the subject however are separated by a morpheme identical in form to an accusative pronoun agreeing in gender and number with the subject. In (61) and (62) the subject and predicate are of different genders; in (63) they are of different numbers. In each case this "pronominal augment", as it is known, agrees with the subject rather than the predicate.

(61) Is é Seán an ghasóg a chabhraigh liom. COP MASC.SG Seán(MASC) the boy.scout(FEM) RELhelp.PAST to.me 'Seán is the boy scout who helped me.'

(62) Is í Máire an cailín is airde sa rang. COP FEM.SG Máire(FEM)the girl(MASC) COP.REL tallest in.the class 'Máire is the tallest girl in the class.'

(63) Is iad na daoine sin an coiste.

COP PL those people the committee

'Those people are the committee.'

Doherty (1996a), following a suggestion from Ken Hale, argues that the pronominal augment is an agreement particle, hence an $\mathrm{Agr}^{\circ}$. In this case, there is no trace in $\mathrm{Agr}^{\circ}$, and is in $\mathrm{C}^{\circ}$ is syntactically adjacent to the augment in $\mathrm{Agr}^{\circ}$. We predict resyllabification here, and as shown above in (33), the prediction is borne out: the $s$ of the copula becomes the onset of the following syllable, and takes the latent [-back] onset to surface as [j]. Usually the copula undergoes aphaeresis as well (cf. (55)), so that is é, is $i$, is iad, is $e a$ surface as [ [e: $\int \mathrm{i}: \int \mathrm{j}$ iəd $\left.\int \mathrm{a}\right]$.

\subsection{Copular forms before lexical words in subordinate clauses}

In clauses introduced by a subordinating complementiser such as the indirect relative particle $a N$ (cf. McCloskey 1979 for discussion) or the indirect speech particle go 'that', present-tense copular features are incorporated into the complementiser; their presence is indicated phonologically by the presence of an $-r$ at the end of the complementiser. This $-r$ is not present before verbs in the present tense. ${ }^{20}$

(64) Indirect relative clauses

a. an duine ar cuimhin leis the person aN.COP.PRES memory with.him 'the person who remembers'

b. an poll a dtagann na coiníní as the hole aN come.PRES the rabbits out.of.it 'the hole which the rabbits come out of' 
(65) Indirect speech clauses

a. Deirsí gur maith an fear é.

says she that.COP.PRES good the man him

'She says that he is a good man.'

b. Deirsé go gcreideann sé í.

says he that believe.PRES he her

'He says that he believes her.'

In the past tense, these complementiser + copula complexes are followed by lenition of the initial consonant of a following word. The complementiser itself does not change form before a consonant-initial word in the past tense.

(66) a.
an duine ar
chuimhin leis
(cf. (64a))
the person aN.COP.PAST memory
with.him

'the person who remembered'

b. Dúirt sí gur mhaith an fear é. (cf. (65a))
said she that.COP.PAST good the man him

'She said that he was a good man.'

One possible analysis is that when the copular features move from $\mathrm{Agr}^{\circ}$ to $\mathrm{C}^{\circ}$, they leave behind them a lenition trigger in the past tense or a non-lenition trigger in the present tense:

(67)

a.

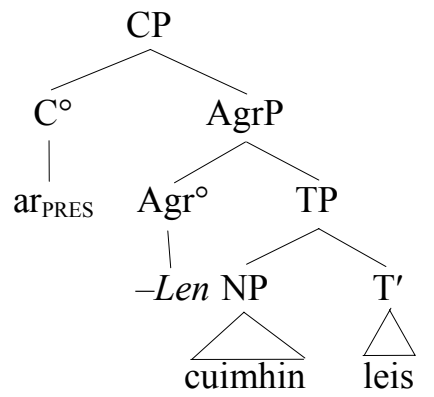

b.

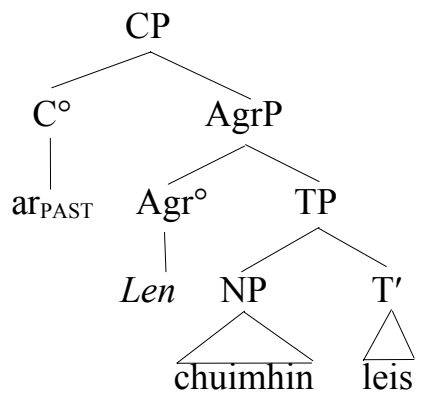

Before vowel-initial words, though, the presence or absence of lenition could not be seen since only consonants undergo lenition. In this case, an epenthetic $b$ is inserted in $\mathrm{Agr}^{\circ}$; in the present tense it remains as [b]; in the past, it undergoes lenition to [v], spelled $b h^{21}$
(68) a.
an duine $\underline{\mathrm{arb}}$
eol dó
the person aN.COP.PRES known to.him
'the person who knows' 
b. an duine arbh eol dó

the person aN.COP.PAST known to.him

'the person who knew'

(69) a. Deir sí gurb eagal dó.

says she that.COP.PRES danger to.him

'She says that he is in danger.'

b. Dúirt sí gurbh eagal dó.

said she that.COP.PAST danger to.him

'She said that he was in danger.'

As discussed above in $\S 3.2$, there is no epenthesis between the $r$ and the $b(h)$ in these forms; further, the $b(h)$ undergoes resyllabification and, where applicable, [back] spreading. This indicates that $a r / g u r$ is external to the pword but that $b(h)$ is syllabified as the onset of the pword.

(70) a. arb eol dó [эr $\omega_{\omega}\left(b^{j} \mathrm{o}: 1\right)$ do:]; arbh eol dó [эr $\omega_{\omega}\left(\mathrm{v}^{\mathrm{j}} \mathrm{o}: 1\right)$ do:]

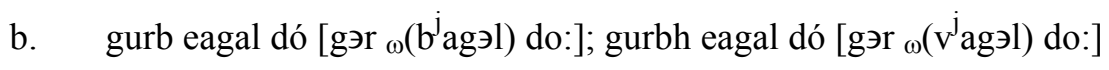

These facts would seem to indicate that $b(h)$ is found under $\operatorname{Agr}^{\circ}$ and merges with the (non-)lenition trigger found there. Since there is no trace between $\mathrm{Agr}^{\circ}$ and the following predicate, resyllabification is correctly predicted.

(71) a.

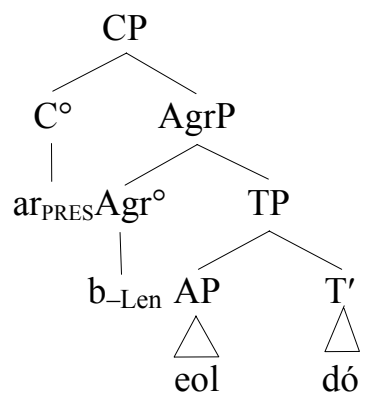

b.

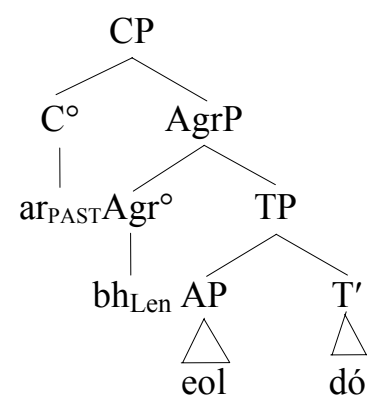

In this case it is not clear whether to regard $\left[{ } \mathrm{r}_{\omega}\left(\mathrm{v}^{\mathrm{j}} \mathrm{O}: 1\right)\right]$ etc. as cases of a morpheme split across a pword boundary or not. Carnie (1995: 132) calls the $b h$ that appears in past/conditional copular forms "a clear lenited reflex of the $b a$ allomorph of the $i s$ morpheme", but it is unclear why the allomorph marked for past/conditional should also be used in present-tense contexts like arb eol dó 'who knows'. Historically the $b$ derives from the present subjunctive of the Old Irish copula, but in Modern Irish the copula has no distinct subjunctive forms. The $b(h)$ is probably best regarded either as epenthetic in the prevocalic cases, or else as underlyingly present but deleted before consonants. 


\section{Conclusion}

In this paper, I have shown firstly that it is possible for a single language to employ more than one type of clitic structure in order to comply with phonological well-formedness considerations, and secondly that it is possible for a pword to consist not only of complete morphemes but of morphologically arbitrary strings of sounds as well. We have seen that Irish typically uses a free clitic structure $\phi_{(}\left(\mathrm{Clitic}_{\omega}(\mathrm{Host})\right)$ but that the internal clitic structure $\omega_{\omega}(\mathrm{Clitic}+\mathrm{Host})$ is found when a $\mathrm{Cv}$ proclitic undergoes elision before a vowel-initial host in order to avoid hiatus. Further, a consonant-final proclitic may undergo resyllabification before a vowel-initial host if no trace intervenes. In this case, a morpheme will be split across a pword boundary; the pword will consist of a morphologically "stray" consonant followed by a lexical word.

\section{Notes}

* Thanks to Artemis Alexiadou, Andrew Carnie, Cathal Doherty, Tracy Alan Hall, Paul Law, Maitias Mac Cárthaigh, André Meinunger, Máire Ní Chiosáin, Meidhbhín Ní Úrdail, Dónall Ó Baoill, Brian Ó Conchubhair and Aonghus Ó hAlmhain for their help. Thanks also to the audience at the clitics workshop at the 21st Annual Meeting of the German Linguistics Society in February 1999 in Konstanz and to Birgit Gerlach and Janet Grijzenhout for organising the workshop.

${ }^{1}$ In this paper I describe the morphological behaviour of standard Irish, as set out e.g. in Gramadach na Gaeilge (1958) and Christian Brothers (1994). The standard does not correspond in every detail to any one of the spoken dialects (Munster, Connacht, Ulster), but every aspect of the standard can be illustrated from at least one of the spoken dialects. I mostly cite the pronunciation given in the source from which I drew the example, but occasionally I turn to the standardised pronunciation called the Lárchanúint ('central dialect'), described in Ó Baoill (1986). Foclóir Póca (1986) gives the Lárchanúint pronunciation for each of its head-words; words cited from this source are indicated by FP. I abstract away from the contrast between "tense" and "lax" sonorants seen in some dialects.

Although some speakers do not follow the patterns described here, after reading transcribed texts, listening to tapes and asking speakers' opinions, I am satisfied that the generalisations I make hold true for most Irish speakers.

2 Throughout this paper I will frequently use the term "clitic" interchangeably with "proclitic". I have not had a chance to examine Irish enclitics.

${ }^{3}$ There are a few exceptions: [s] rather than [〕] occurs in word-initial position before palatalised labials (e.g. sméara [sm ${ }^{\mathrm{j}} \mathrm{e}: \mathrm{r} \ni$ ] 'blackberries', spion [sp $\left.{ }^{\mathrm{j}} \mathrm{i}: \mathrm{n}\right]$ 'spine': FP); velarised $r$ occurs before palatalised coronals (e.g. aird [a:r $\mathrm{r}^{\gamma} \mathrm{d}^{\mathrm{j}}$ '] 'direction', comhairle

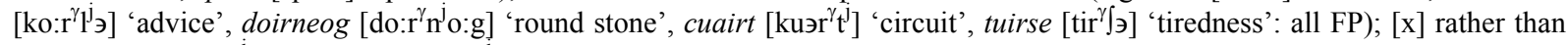
[c] occurs before $\left[\mathrm{t}^{\mathrm{j}}\right]$ (e.g. bhoicht $\left[\right.$ voxt $\mathrm{j}^{\mathrm{j}}$ ' 'poor' (voc. sg. masc.): Breatnach 1947, 139).

${ }_{5}^{4}$ In the idiom Aithnionn ciaróg ciaróg eile 'A beetle recognises another beetle', i.e. 'Birds of a feather flock together'.

5 This gap cannot be attributed in Irish, as it can in English, to a general prohibition on $t$ - clusters, since Irish permits wordinitial $t l$. Irish further permits word-initial $t n$ and $k n$, but not $s t n$ or $s k n$.

${ }^{6}$ Aphaeresis of the copula is not always possible. In sentences with indefinite NP complements like Is aturnae mé 'I am a solicitor', aphaeresis is apparently ungrammatical: *'S aturnae mé, although complete deletion of the copula is permissible: Aturnae mé. In many sentences with other complements, on the other hand, such as Is maith liom é 'I like it' (maith 'good') or Is amhlaidh a rinne sé é 'it's like this he did it' (amhlaidh 'thus'), aphaeresis is quite common while deletion is ungrammatical or at least dispreferred: 'S maith liom é and 'S amhlaidh a rinne sé é but *?Maith liom é, *Amhlaidh a rinne séé.

7 Recent dictionaries of Irish list certain modern "international" loan-words with initial $s f$-; examples from FP include $s f a g$ nam 'sphagnum', sféar 'sphere', sféarúil 'spherical' and sfioncs 'sphinx'. These words are of course all very marginal, not to say artificial, in the Irish lexicon. No source older than the 1970s that I am aware of lists a single Irish word with an initial $s f$ - cluster.

${ }^{8}$ Stems that cause palatalisation did begin with front vowels in Old Irish, and roots that cause velarisation began with back vowels in Old Irish. However, historical sound change has changed the backness of many vowels in Irish, so that synchronically in Modern Irish there is no correlation between the backness feature that attaches to preceding consonants and the backness of the stem-initial vowel itself. In the orthography, a velarising stem is spelled with an initial $a, o$ or $u$, a palatalising stem with $e$ or $i$.

${ }^{9}$ McCarthy \& Prince (1993) analyse similar data from Polish with an alignment constraint on left edges rather than on right

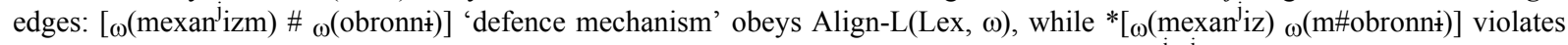
it. In Polish, there is also no resyllabification after proclitic elements like prefixes: [roz $\left.\omega_{\omega}\left(\operatorname{ogn}^{j}{ }^{j} \mathrm{c}^{\mathrm{j}}\right)\right]$ ' 'heat'. In Irish, on the other hand, there is resyllabification after proclitics, but not after lexical words, which indicates that it is the right edge of lexical word 1 rather than the left edge of lexical word 2 that is impenetrable in Irish.

${ }^{10}$ While resyllabification across word boundaries is not unusual cross-linguistically, I know of no other language but Irish 
where cross-word resyllabification is reported to be permitted only in certain syntactic circumstances and not in others.

${ }^{11}$ The preterite marker do is normally omitted before consonant-initial words. Forms like do thoiligh are distinctly archaic or literary.

${ }^{12}$ The prepositions $d o$ 'to, for' and $d e$ 'of, from' are pronounced $\left[\mathrm{d}^{\gamma} \mathrm{o}\right]$ and $\left[\mathrm{d}^{\mathrm{j}} \mathrm{e}\right]$ respectively. But these vowels may well be placeless in principle, having received [back] specification from the onset consonant. At any rate, these two prepositions behave like other $\mathrm{Cv}$ proclitics in undergoing elision before a vowel-initial stem. Other $\mathrm{Cv}$ prepositions cause mutations such as $n$ insertion (eclipsis) or $h$-insertion before vowel-initial stems and hence do not undergo elision.

13 Since NoHIATUS is more specific than ONSET, in the sense that a NOHIATUS violation entails an ONSET violation, but the opposite is not the case, the ranking NoHiATUS » ONSET is predicted by Panini's Theorem (Prince \& Smolensky 1993, 81).

${ }^{14}$ I do not have space here to examine the issue of why it is the [back] specification of the lexical word rather than that of the clitic that surfaces; i.e. why $/ b^{\gamma}{ }_{\ni}+{ }^{j} a: r /$ surfaces as $\left[b^{j} a: r\right]$ rather than $\left[b^{\gamma} a: r\right]$; presumably the relative importance of lexical words in comparison to function words plays a role.

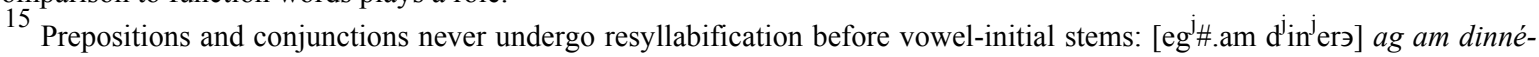
ara 'at dinnertime' (Ulster: Hughes 1986, 4); [o:1 agəs\#.içэ] ól agus ithe 'drinking and eating' (Connacht: de Búrca 1958, 100). One could suggest a constraint aligning the right edge of a preposition or conjunction with the right edge of a syllable. Such a

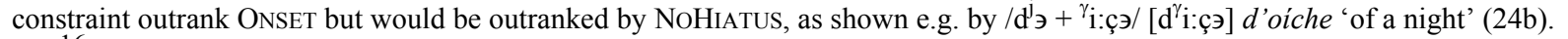

${ }^{16}$ Before a pronominal augment, the aphaeretic form [ [] is usually found. As discussed below in $\S 3.3$, aphaeresis is common before other parts of speech as well, but with pronominal augments, forms like [ $\left.\int \mathrm{e}: \int \mathrm{i}: \int \mathrm{a} \int \mathrm{i} \ni \mathrm{d}\right]$ are actually far more frequent than

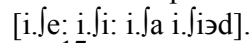

17 ' $\mathrm{aL}$ ' and 'aN' refer respectively to the direct and indirect relative particles of Irish. See McCloskey (1979) for definitions and discussion of the difference between the two.

${ }^{18}$ Chung \& McCloskey (1987), Guilfoyle (1990) and McCloskey (1991) argue that the verb has moved out of $\mathrm{V}^{\circ}$ and into $\mathrm{I}^{\circ}$ in structures like (38a). I assume, following Doherty (1996a), that IP in Irish is actually expanded into AgrP dominating TP, and that the verb moves through $\mathrm{T}^{\circ}$ before landing in Agr $^{\circ}$. See $\S 4$ for discussion.

${ }^{19}$ For ease of exposition, I treat the aphaeretic form of the copula as if it had its own underlying representation /s/, rather than being affiliated with the input/is/. I do not have space here to go into the question of variation between the full and aphaeretic forms of the copula.

${ }^{20}$ Complementisers before past-tense verbs do end in -r, e.g. an poll ar tháinig na coiníní as (the hole aN.PAST came the rabbits out.of.it) 'the hole which the rabbits came out of'; Dúirt sé gur chreid sé $i$ (said he that.PAST believed he her) 'He said that he believed her'. This homophony of gur 'that.COP.PRES' and gur 'that.PAST' is presumably coincidental.

${ }^{21}$ Gur 'that.PAST' and similar forms do not take this epenthetic $b$ before vowels (e.g. Dúirt mé gur éirigh mé (said I that.PAST arose I) 'I said that I got up'), which can be taken as concrete evidence that gur 'that.PAST' and gur 'that.COP.PRES' are formally distinct from each other and only coincidentally homophonous.

\section{References}

Booij, G. E. 1996. "Cliticization as prosodic integration: the case of Dutch." Linguistic Review 13: 219-242.

Breatnach, R. B. 1947. The Irish of Ring, Co. Waterford: a Phonetic Study. Dublin: Dublin Institute for Advanced Studies.

Carnie, A. 1995. Non-verbal predication and head-movement. Ph.D. dissertation, MIT.

Christian Brothers. 1994. New Irish Grammar. Dublin: Fallon.

Chung, S. \& J. McCloskey. 1987. "Government, barriers and small clauses in Modern Irish." Linguistic Inquiry 18: 173-237.

de Bhaldraithe, T. 1945. The Irish of Cois Fhairrge, Co. Galway. Dublin: Dublin Institute for Advanced Studies.

de Bhaldraithe, T. 1953. Gaeilge Chois Fhairrge: an Deilbhiocht. Dublin: Dublin Institute for Advanced Studies.

de Búrca, S. 1958. The Irish of Tourmakeady, Co. Mayo. Dublin: Dublin Institute for Advanced Studies.

Doherty, C. 1996a. "Clausal structure and the Modern Irish copula." Natural Language and Linguistic Theory 14: 1-46.

Doherty, C. 1996b. "Predicate initial constructions in Irish." In The Proceedings of the Fifteenth West Coast Conference on Formal Linguistics, B. Agbayani \& S.-W. Tang (eds.), 81-95. Stanford: Stanford Linguistics Association.

Foclóir Póca: English-Irish/Irish-English Dictionary 1986. Dublin: An Gúm.

Gramadach na Gaeilge agus Litriú na Gaeilge 1958. Dublin: Oifig an tSoláthair.

Guilfoyle, E. 1990. Functional categories and phrase structure parameters. Ph.D. dissertation, McGill University.

Hall, T. A. 1999. German phonotactics and the prosodic structure of function words. In Studies on the Phonological Word, T. A. Hall \& U. Kleinhenz (eds.), 99-131. Amsterdam: Benjamins.

Hamilton, J. N. 1974. A Phonetic Study of the Irish of Tory Island, Co. Donegal. Belfast: Institute of Irish Studies, The Queen's University of Belfast. 
Hayes, B. 1989. "The prosodic hierarchy in meter." In Phonetics and Phonology, Volume 1: Rhythm and Meter, P. Kiparsky \& G. Youmans (eds.), 201-260. San Diego: Academic Press.

Holmer, N. M. 1962. The Dialects of Co. Clare. Dublin: Royal Irish Academy.

Hughes, A. J. 1986. The Gaelic of Tangaveane and Commeen, County Donegal. Ph.D. dissertation, Queen's University of Belfast.

Inkelas, S. 1989 (1990). Prosodic Constituency in the Lexicon. New York: Garland.

Kayne, R. S. 1994. The Antisymmetry of Syntax. Linguistic Inquiry Monograph 25. Cambridge, Mass.: MIT Press.

McCarthy, J. J. \& A. S. Prince. 1993. "Generalized alignment.” In Yearbook of Morphology, G. Booij \& J. van Marle (eds.), 79153. Dordrecht: Kluwer.

McCloskey, J. 1979. Transformational Syntax and Model Theoretic Semantics. Dordrecht: Reidel.

McCloskey, J. 1991. "Clause structure, ellipsis and proper government in Irish.” Lingua 85: 259-302.

Mhac an Fhailigh, É. 1968. The Irish of Erris, Co. Mayo. Dublin: Dublin Institute for Advanced Studies.

Nespor, M. and Vogel, I. 1986. Prosodic Phonology. Dordrecht: Foris.

Ní Chiosáin, M. 1991. Topics in the phonology of Irish. Ph.D. dissertation, UMass-Amherst.

Ní Chiosáin, M. 1994. "Vowel features and underspecification: evidence from Irish." In Phonologica 1992: Proceedings of the Seventh International Phonology Meeting, Krems, Austria, W. U. Dressler, M. Prinzhorn \& J. R. Rennison (eds.), 157-164. Turin: Rosenberg.

Ní Chiosáin, M. 1995a. Optimal forms of vowel stems in Irish. Talk given at the First Celtic Linguistics Conference, Dublin, 22 June 1995.

Ní Chiosáin, M. 1995b. Prosodic well-formedness and sonority constraints: epenthesis in Irish. Ms., University College Dublin. ROA-89-0000, Rutgers Optimality Archive, ruccs.rutgers.edu/roa.html.

Ní Chiosáin, M. 1999. Syllables and phonotactics in Irish. In The Syllable: Views and Facts, H. van der Hulst \& N. A. Ritter (eds.), 551-575. Berlin: Mouton de Gruyter.

Ó Baoill, D. P. 1986. Lárchanúint don Ghaeilge. Dublin: Linguistics Institute of Ireland.

Ó Cuív, B. 1944. The Irish of West Muskerry, Co. Cork. Dublin: Dublin Institute for Advanced Studies.

Ó Searcaigh, S. 1925. Foghraidheacht Ghaedhilge an Tuaiscirt. Belfast: Browne \& Nolan.

Ó Siadhail, M. 1989. Modern Irish: Grammatical Structure and Dialectal Variation. Cambridge: Cambridge University Press.

Peperkamp, S. 1997. Prosodic Words. The Hague: Holland Academic Graphics.

Prince, A. S. and Smolensky, P. 1993. Optimality Theory: constraint interaction in generative grammar. Ms., Rutgers University and University of Colorado at Boulder.

Quiggin, E. C. 1906. A Dialect of Donegal. Cambridge: Cambridge University Press.

Rotenberg, J. 1978. The syntax of phonology. Ph.D. dissertation, MIT.

Selkirk, E. O. 1984. Phonology and Syntax: The Relation between Sound and Structure. Cambridge, Massachusetts: MIT Press.

Selkirk, E. O. 1986. "On derived domains in sentence phonology." Phonology Yearbook 3: 371-405.

Selkirk, E. O. 1995. "The prosodic structure of function words." In Papers in Optimality Theory: University of Massachusetts Occasional Papers Volume 18, J. N. Beckman, L. Walsh Dickey \& S. Urbanczyk (eds.), 439-469. Amherst: GLSA, UMassAmherst.

Sjoestedt, M. L. 1931. Phonétique d'un parler irlandais de Kerry. Paris: Leroux.

Sjoestedt-Jonval, M. L. 1938. Description d'un parler irlandais de Kerry. Paris: Champion.

Sommerfelt, A. 1965. "Phonetic texts from the dialect of Torr, Co. Donegal." Lochlann 3: 375-403.

Wagner, H. 1959. Gaeilge Theilinn. Dublin: Dublin Institute for Advanced Studies.

Zec, D. and Inkelas, S. 1991. "The place of clitics in the prosodic hierarchy." In Proceedings of WCCFL 10, D. Bates (ed.), 505519. Stanford: CSLI. 